$2^{24} 52^{9} \mid 64$

IDO-17258H

April 1969

MASTER

\title{
CAROLINAS VIRGINIA TUBE REACTOR (CVTR) IN-PLANT TESTING PROJECT
}

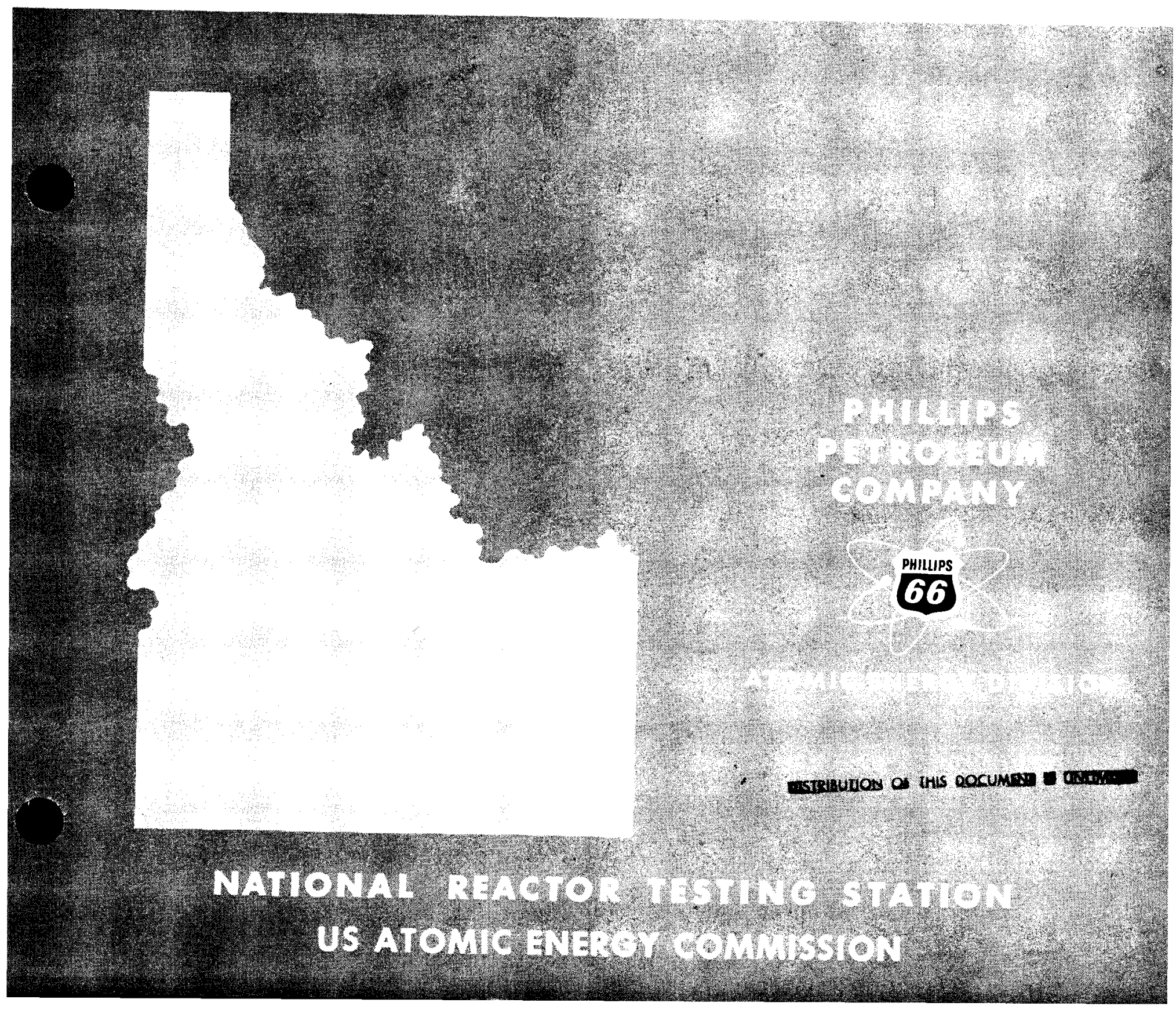




\section{DISCLAIMER}

This report was prepared as an account of work sponsored by an agency of the United States Government. Neither the United States Government nor any agency Thereof, nor any of their employees, makes any warranty, express or implied, or assumes any legal liability or responsibility for the accuracy, completeness, or usefulness of any information, apparatus, product, or process disclosed, or represents that its use would not infringe privately owned rights. Reference herein to any specific commercial product, process, or service by trade name, trademark, manufacturer, or otherwise does not necessarily constitute or imply its endorsement, recommendation, or favoring by the United States Government or any agency thereof. The views and opinions of authors expressed herein do not necessarily state or reflect those of the United States Government or any agency thereof. 


\section{DISCLAIMER}

Portions of this document may be illegible in electronic image products. Images are produced from the best available original document. 
Printed in the Unxted States of America Available from

Clearinghouse for Federal Scientific and Technical Information

National Bureau of Standards, U. S. Department of Commerce

Springfield, Virginia 22151

Price: Printed Copy $\$ 3.00$; Microfiche $\$ 0.65$

\section{LEGAL NOTICE}

This report was prepared as an account of Government sponsored work Nether the Unted States, nor the Commission, nor any person acting on behalf of the Commission

A Makes any warranty or representation, express or implied, with respect to the accuracy, completeness, or usefulness of the information contaned in this report, or that the use of any information, apparatus, method, or process disclosed in this report may not infringe privately owned rights, or

B Assumes any habilities with respect to the use of, or for damages resulting from the use of any information, apparatus, method or process disclosed in the report

As used in the above, "person acting on behalf of the Commission" includes any employee or contractor of the Commission, or employee of such contractor, to the extent that such employee or contractor of the Commission, or employee of such contractor prepares disseminates, or provides access to, any information pursuant to his employment or contract with the Commission, or his employment with such contractor 
IDO-17258H

AEC Research and Development Report

Reactor Technology

TID-4500

LEGAL NOTICE

Thus report was prepared as an account of Government sponsored work. Nerther the United Issued: April 1969 States, nor the Commission, nor any person acting on behnif of the Commission

A. Makes any warranty or representation, expressed or implied, with respect to the accuracy, completeness, or usefulness of the information contained in this report, or that the use of any information, apparatus, method, or process disclosed in this report mas not infringe privately owned rights; or

B. Assumes any liabilties with respect to the use of, or for damages resulting from the use of any information, apparatus, method, or process disclosed in this report.

As used in the above. "person acting on behalf of the Commission" includes any employee or contractor of the Commission, or employee of such contractor, to the extent that such employee or contractor of the Commission, or employee of such contractor prepares. disseminates, or provides access to, any information pursuant to his employment or cuntract with the Commission, or his employment with such contractor.

\section{CAROLINAS VIRGINIA TUBE REACTOR (CVTR) \\ IN-PLANT TESTING PROJECT}

S. G. Forbes

ASSISTANT MANAGER TECHNICAL

ATOMIC ENERGY DIVISION

T. R. Wilson

MANAGER

LOFT PROGRAM OFFICE
N. K. Sowards

MANAGER

PLANT APPLICATIONS

AND ENGINEERING TESTS

BRANCH

\section{PHILLIPS}

PETROLEUM

COMPANY

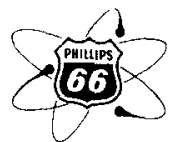

Atomic Energy Division

Contract AT(10 1)-205

Idaho Operations Office

U. S. ATOMIC ENERGY COMMISSION 
AUTHOR - TECHNICAL CONTACT

J. A. Norberg

CONTRIBUTORS

G. E. Bingham

D. A. Waddoups

R. C. Schmitt 
I. INTRODUCTION $\ldots \ldots \ldots \ldots \ldots \ldots \ldots \ldots \ldots \ldots \ldots \ldots$

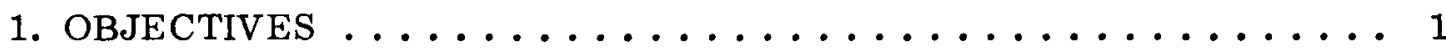

2. RELATIONSHIP TO OTHER NUCLEAR SAFETY PROGRAMS $\ldots \ldots \ldots$

3. ACCOMPLISHMENTS ................. 2

3.1 Containment Contaminants Studies. . . . . . . . . . 2

3.2 Leakage Rate Test Results . . . . . . . . . . . . . 2

3.3 Dynamic Structural Vibration Properties . . . . . . . . . . 3

4. REPORTING MEDIA AND AVAILABLE REFERENCE SOURCES . . . 3

II. PURPOSE AND JUSTIFICATION $\ldots \ldots \ldots \ldots \ldots \ldots \ldots \ldots$

1. Containment le akage studies $\ldots \ldots \ldots \ldots \ldots \ldots \ldots$

2. CONTAINMENT RESPONSE TO DESIGN BASIS ACCIDENT (DBA)

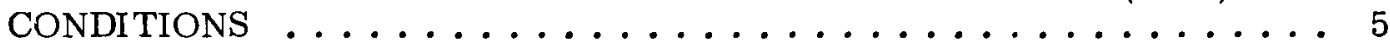

3. CONTAINMENT STRUCTURAL VIBRATION PROPERTIES . . . . . 6

III. PROGRAM DESCRIPTION $\ldots \ldots \ldots \ldots \ldots \ldots \ldots \ldots$

1. StRUCTURAL VIBRATION TESTS $\ldots \ldots \ldots \ldots \ldots \ldots \ldots \ldots$

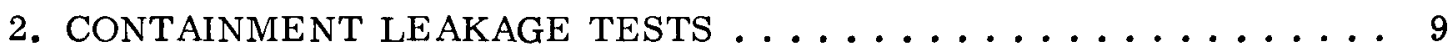

2.1 Ambient Air Leakage Rate Tests.............. 9

2.2 Hot Air Leakage Rate Tests . . . . . . . . . . . . 10

3. DESIGN BASIS ACCIDENT TESTS. ............. 11

3.1 Steam Test -- Natural Pressure Decay . . . . . . . . . 12

3.2 Steam Tests - Spray Pressure Reduction . . . . . . . . 12

3.3 System Operational Demonstration Tests . . . . . . . . 12

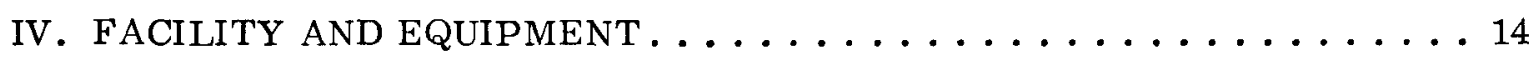

1. FACILITY DESCRIPTION ................. 14

1.1 CVTR Containment System. . . . . . . . . . . . 14

1.2 Steam Supply System . . . . . . . . . . . . . . . 14

1.3 Containment Pressure Reduction Spray System . . . . . . . 16

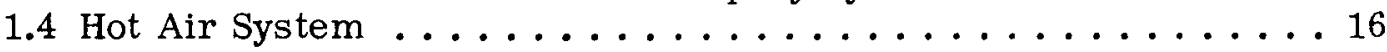

1.5 Controlled Leak Systems . . . . . . . . . . . . 16

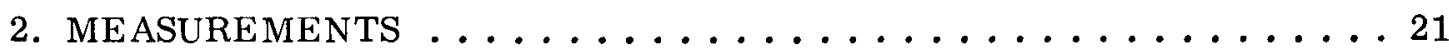

2.1 Measurements for Containment Leakage Tests $\ldots \ldots \ldots \ldots \ldots 21$ 
2.2 Measurements for DBA Steam Tests . . . . . . . . . . . 24

2.3 Measurements for Structural Vibration Tests ............ 30

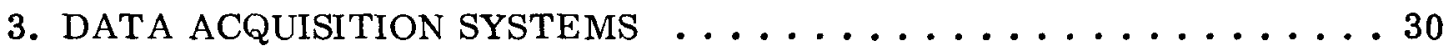

3.1 Digital Data Acquisition System ... . . . . . . . . . 30

3.2 Analog Data Multiplexing System................. 30

3.3 Recording Oscillograph System.................. 31

3.4 Digital Voltmeter System................... . 31

V. PROGRAM DESCRIPTION BEYOND FY $-1969 \ldots \ldots \ldots \ldots \ldots$

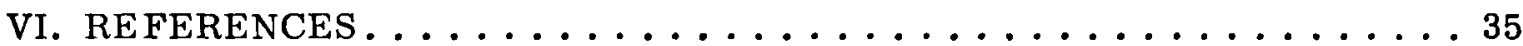

FIGURES

1. CVTR containment structure . . . . . . . . . . . . . 15

2. CVTR steam addition system .................... 17

3. CVTR pressure reduction spray system $\ldots \ldots \ldots \ldots \ldots$

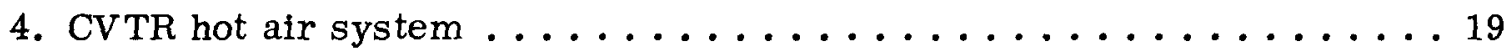

5. Controlled leak system used for preliminary tests ... . . . . . . 20

6. Controlled leak system used for integrated leakage tests and DBA

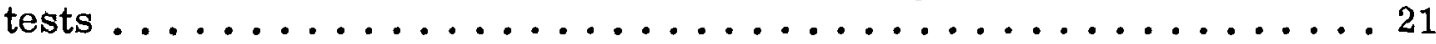

7. Reference vessel system ...................... 22

8. Absolute and differential pressure measuring system ..........23

9. Surface temperature measuring system $\ldots \ldots \ldots \ldots \ldots \ldots \ldots$

10. Containment vessel humidity measuring system $\ldots \ldots \ldots \ldots \ldots \ldots$

11. Transient pressure measuring system $\ldots \ldots \ldots \ldots \ldots \ldots$

12. Temperature profile measuring system ............... 28

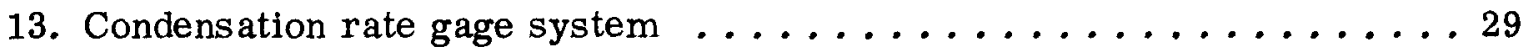

14. Digital data acquisition system $\ldots \ldots \ldots \ldots \ldots \ldots \ldots \ldots \ldots \ldots \ldots$

15. Analog data multiplexing system . . . . . . . . . . . . . . 32

16. Recording os cillography system .................. 32

17. Digital voltmeter and digital printer systems $\ldots \ldots \ldots \ldots \ldots \ldots$ 
TABLE

I. CVTR In-Plant Testing Project Schedule ............... 8 


\section{CAROLINAS VIRGINIA TUBE REACTOR (CVTR) IN-PLANT TESTING PROJECT}

\section{IN?"RODUCTION}

The CVTR In-Plant Testing Project is being performed in the Carolinas Virginia Tube Reactor (CVTR) facility at Parr, South Carolina, by the Plant Applications and Engineering Tests (PA\&ET) Branch of Phillips Petroleum Company and the Carolinas Virginia Nuclear Power Associates (CVNPA). This project is to provide realistic information on containment system behavior that can be used to evaluate and improve analytical and experimental techniques, thus allowing increased confidence in applying such techniques to safety analysis of nuclear power plants.

\section{OBJECTIVES}

The primary objectives of this project are: (a) to obtain data on the pressuretemperature response of the CVTR containment system to simulated design basis accident (DBA) conditions [a] and to compare these data with response predictions obtained through use of current analytical techniques, (b) to assess the effectiveness of a containment pressure reduction spray system, (c) to determine structural dynamic vibrational properties for comparison with predictions acquired from state-of-the-art seismic analyses, and (d) to evaluate procedures, instrumentation, and assumptions commonly utilized in leakage rate testing of power reactor containments.

Secondary objectives of the program are: (a) to measure the containment leakage rate as a function of pressure and temperature and (b) to evaluate the effect of DBA conditions on leakage rate, vessel strain, and engineered safety system operation.

\section{RELATIONSHIP TO OTHER NUCLEAR SAFETY PROGRAMS}

The CVTR In-Plant Testing Project is related to the separate effects tests program of the LOFT-ESS program. Experimental results from the CVTR program will be used to evaluate typical analytical models for containment response such as CONTEMPT [1]. Performance results of the containment pressure reduction spray system used in CVTR will be used to

[a] DBA conditions, as used in this description, are containment environmental conditions resulting from a postulated loss-of-coolant accident, such as a primary system pipe break. The usual condition is an air-steam mixture with a pressure and temperature dependent on the particular reactor. The tests at CVTR are not expected to exceed the postulated maximum design accident conditions, which are 21 psig, $215^{\circ} \mathrm{F}$, and $100 \%$ humidity, for that plant. No attempt is being made to model any actual postulated CVTR accident. 
evaluate the design of a similar system in LOFT. The results of the CVTR leakage rate test can contribute to specification of requirements and procedures for the LOFT leakage evaluation.

The CVTR project is also closely related to portions of the Containment System Experiment at Battelle Northwest Laboratories and directly related to $\mathrm{AEC}$ efforts for providing more assurance in the adequacy of safety analysis of nuclear plants. The CVTR structural vibration work will contribute to the Anti-Seismic Program at ORNL.

\section{ACCOMPLISHMENTS}

A preliminary in-plant testing effort was performed at CVTR during the third and fourth quarters of FY-1967. The program included two tasks: (a) containment contaminants measurements and (b) testing and evaluation of the continuous leakage rate measurement system. Instrumentation installations and facility modifications necessary for performing primary containment leakage studies and for performing the design basis accident tests were completed during the first part of FY-1969. An Ambient Vibration Survey (natural excitation) and forced vibration (shaker excitation) survey for vibrational properties of the CVTR containment were completed during the first quarter of FY-1969. Analysis of results and comparison to predictions from seismic analytical models are currently in progress. Containment integrated leakage rate tests using air at both ambient and elevated temperatures and at several pressures up to the DBA condition were completed during the second and third quarters of FY -1969; data reduction and analys is are in progress.

\subsection{Containment Contaminants Studies}

A series of contaminant measurements were made at CVTR to detect and identify specific organic compounds in the containment environment. The data obtained will aid in evaluating large-scale filtration units.

Results of contaminant (airborne hydrocarbons) studies were as follows: (a) contaminants collected from the containment air were $88 \%$ unsaturated and $69 \%$ oxygenated; of the material collected on charcoal, $87 \%$ was in the 69 to $174^{\circ} \mathrm{C}$ boiling range; (b) only $1.2 \%$ of the contaminants in the containment air were adsorbed on the charcoal sample traps, and (c) containment air contamination at CVTR was $54.3 \mathrm{ppm}$ by volume as compared to 0.072 to $0.121 \mathrm{ppm}$ found in buildings housing ORNL reactors. Charcoal exposed to CVTR containment atmosphere showed a significant drop in methyl iodide removal efficiency when the charcoal contaminant level reached $7.05 \mathrm{wt} \%$.

\subsection{Leakage Rate Test Results}

The preliminary leakage rate tests were done with the nuclear reactor shut down and the containment conditions as near normal operating conditions as possible. CVTR was normally operated at a slight overpressure with a reference system in operation for a continuous leakage behavior record (versus the more typical periodic leak measurements). During preliminary leakage tests various leakage rates were imposed on the containment system to determine 
the effectiveness of the continuous leakage rate system as a leakage indicator. A z-psig test pressure was used, and the leakage was measured by both absolute and reference vessel methods.

The continuous leakage rate system was found to be both sensitive and accurate. The results of this test confirmed the usefulness of a continuous leakage rate measurement system for a power reactor. Such a system provides accurate knowledge of the containment leakage during reactor operation and indicates, within hours, whether the containment has developed a leak and the relative size of the leak.

Additionally, a determination of the CVTR leakage rate with no imposed leaks was made. The containment leakage rate from the 2-psig test was between 0.095 and $0.12 \%$ per day. If a laminar flow regime is assumed for leakage paths, the extrapolation by previously used CVNPA methods results in a $0.51 \%$ per day leakage rate at 13 psig. This leakage is considerably higher than measured during earlier CVNPA 13-psig tests [2]. The higher leakage rate was due to sources of leakage that were not present under normal operating conditions. Additional information concerning this test has been reported[3].

Integrated leakage rate tests which were pertormed during the seconu and third quarters of FY-1959 are discussed in detail in Section III as part of the program description.

\subsection{Dynamic Structural Vibration Properties}

Experimental measurements for the vibrational behavior of the CVTR containment were completed during the first quarter of FY-1969; they included an Ambient Vibration Survey (natural excitation) by Earth Sciences [a] and $t$ shaker study (forced excitation) by the University of California Department of Engineering. Earth Sciences' mathematical modeling and test evaluation have been completed [4] and have resulted in realization of the difficuity in obtaining even partial agreement between analytical predictions and experimental meisurements for a complicated containment structure such as CVTR. Since state-of-the-art analytical techniques were used and changes to the analytics were aliowed, the conclusion is that seismic analytical predictive models for reactor containment structures may be of questionable adequacy and require additional investigation. Evaluation of the shater tests and comparicon to the Ambient Vibration Survey is incomplete to date. A detailed description of these tests is given in Section III, Program Description.

\section{REPORTING MEDIA AND AVAILABLE REFERENCE SOURCES}

Reports presently available discussing the CVTR In-Plant Testing Project and accomplishments are as follows:

1. G. E. Bingham, The Carolinas Virginia Tube Reactor Preliminary Leakage Rate Test Results, IDO-17273 (October 1968)。

2. Reliability Analysis of Carolinas Virginia Tube Reactor Engineered Safety Systems, Holmes \& Narver, Inc., HN-191 (August 1967).

[a] A Teledyne Company. 
3. W. E. Barrow, CVTR Leakage Rate Instrumentation Evaluation, CVNA-295 (November 1967).

4. Carolinas Virginia Nuclear Power Associates, Inc., Final Hazards Summary Report, CVNA-90 (January 1962).

5. Ambient Vibration Survey and Mathematical Analysis of the CarolinasVirginia Tube Reactor, Earth Sciences, A Teledyne Company IDO-ES-616 (ES-616-0968-2127) (September 1968). 


\section{PURPOSE AND JUSTIFICATION}

The availability of the decommissioned CVTR facility provides an opportunity to acquire experimental data on a reactor containment system that otherwise could not be obtained except at much greater expense. Because of the decommmissioned status of the CVTR facility, relatively high risk tests are possible and practical. The data obtained through use of this facility will have direct application to power reactor safety evaluation because the CVTR containment, which is constructed of reinforced concrete with a steel liner for a vapor barrier, is, in both design principle and materials, representative of some of the newest types of power reactor containment structures.

The program encompasses three general areas for containment testing: (a) evaluation of containment leakage measurement techniques and parametric effects on leakage rates, (b) containment response to simulated design bas is accident conditions, and (c) containment structural vibration properties.

\section{CONTAINMENT LEAKAGE STUDIES}

Integrated leakage rate tests similar to those normally required for nuclear facilities to comply with AEC regulatory requirements were performed during the second and third quarters of FY-1969 at both ambient and elevated temperatures for several static pressure conditions. The purposes of these tests were: (a) to determine the adequacy and sensitivity of generally accepted leakagerate measurement techniques used in containment leak testing, (b) to evaluate the effects of temperature and pressure on containment leakage and leakagerate measurements, and (c) to provide base-point data for evaluation of the containment leakage resulting from a DBA occurrence. Some areas of specific interest are: (a) adequacy of extrapolation equations, (b) error analysis, (c) required test durations for acceptable results, and (d) reference vessel design criteria. Results from this testing are expected to contribute significantly to an improved standard by which to judge other facility leakage work. Evaluation of some of these tests is currently in progress.

\section{CONTAINMENT RESPONSE TO DESIGN BASIS}

\section{ACCIDENT (DBA) CONDITIONS}

The ultimate requirement of a containment system is that the system perform satisfactorily under DBA conditions. Knowledge of the containment response to DBA conditions is fundamental to evaluation of power reactor safety. Pressure-temperature-time relationships and the associated structural effects establish a significant part of the information required for determining the amount of radioactive material that could be released to the environment in the event of a loss-of-coolant accident in a power reactor.

The technical specifications of power reactor plants usually require that these plants undergo a containment leakage rate and integrity test at DBA pressure and that they later undergo periodic or continuous leakage rate 
tests at lower pressures. These tests are performed with ambient temperature, low humidity air. Tests at temperatures and humidities representative of DBA conditions are not performed in power reactor containments for obvious operational and economic reasons. Safety evaluations of power reactors, however, require estimates of expected pressure-temperature histories of the containment atmosphere and stress levels of the containment shell for postulated accidents in order to establish the potential for release of radioactive materials. The containment response phase of reactor safety evaluation at present is based largely on analytical techniques. Limited data exist for evaluation of the accuracy and applicability of these techniques; therefore, realistic containment response data are needed for evaluating computational techniques and thereby allowing increased confidence in the safety analysis of power reactors.

The purpose of the CVTR DBA tests is to provide the following experimental information for use in developing and evaluating analytical methods for safety analyses of nuclear power plants:

(1) The temperature-pressure history of a power reactor containment atmosphere subjected to a simulated loss-of-coolant accident

(2) The primary processes controlling the temperature-pressure response of the containment atmosphere

(3) The effectiveness of a typical pressure reduction spray system

(4) The gross effects of loss-of-coolant accident conditions on containment integrity。

The ability of key safety systems and components to function properly during a DBA is essential to the safety of a power reactor. Because of budget considerations, only components and systems that require minimum cost and effort will be investigated during this portion of the CVTR program. If possible, the operation of nuclear instrumentation channels, primary system temperature indicators, pressure- and flow-indicating instrumentation, the emergency coolant injection system, and the recirculating system will be evaluated. The information obtained from these performance evaluations will be used for determining whether the safety systems will operate in a DBA environment.

\section{CONTAINMENT STRUCTURAL VIBRATION PROPERTIES}

Adequate and realistic evaluation of the potential effect of earthquake induced loadings on power reactor systems has long been recognized as an important consideration in the safety analysis and economics of nuclear power plants. Since, potentially, an earthquake can concurrently destroy primary system integrity. breach the containment, and disable crucial safety systems, the need for a verified prediction capability for nuclear plant seismic response is clear. 
To date, the CVTR vibration testing is the most comprehensive experimental effort to evaluate the adequacy of nuclear plant seismic structural analytical models. 


\section{PROGRAM DESCRIPTION}

The testing portion of the CVTR In-Plant Testing Project is to be essentially completed in FY-1969 with only the evaluation and reporting of results extending into the first and second quarters of FY-1970. The schedule for the total program is shown in Table $I$. Instrumentation and facility modifications necessary for performing the test program are complete. Although major portions of the structural vibration work and leakage testing are complete, and were discussed briefly in Section 1.3, Accomplishments, a detailed description of these studies is presented in this section for continuity of the total program description.

The discussion in this section follows the sequence of scheduled test performance; that is, seismic, leakage, and DBA.

\section{TABLE I}

CVTR IN-PLANT TESTING PROJECT SCHEDULE

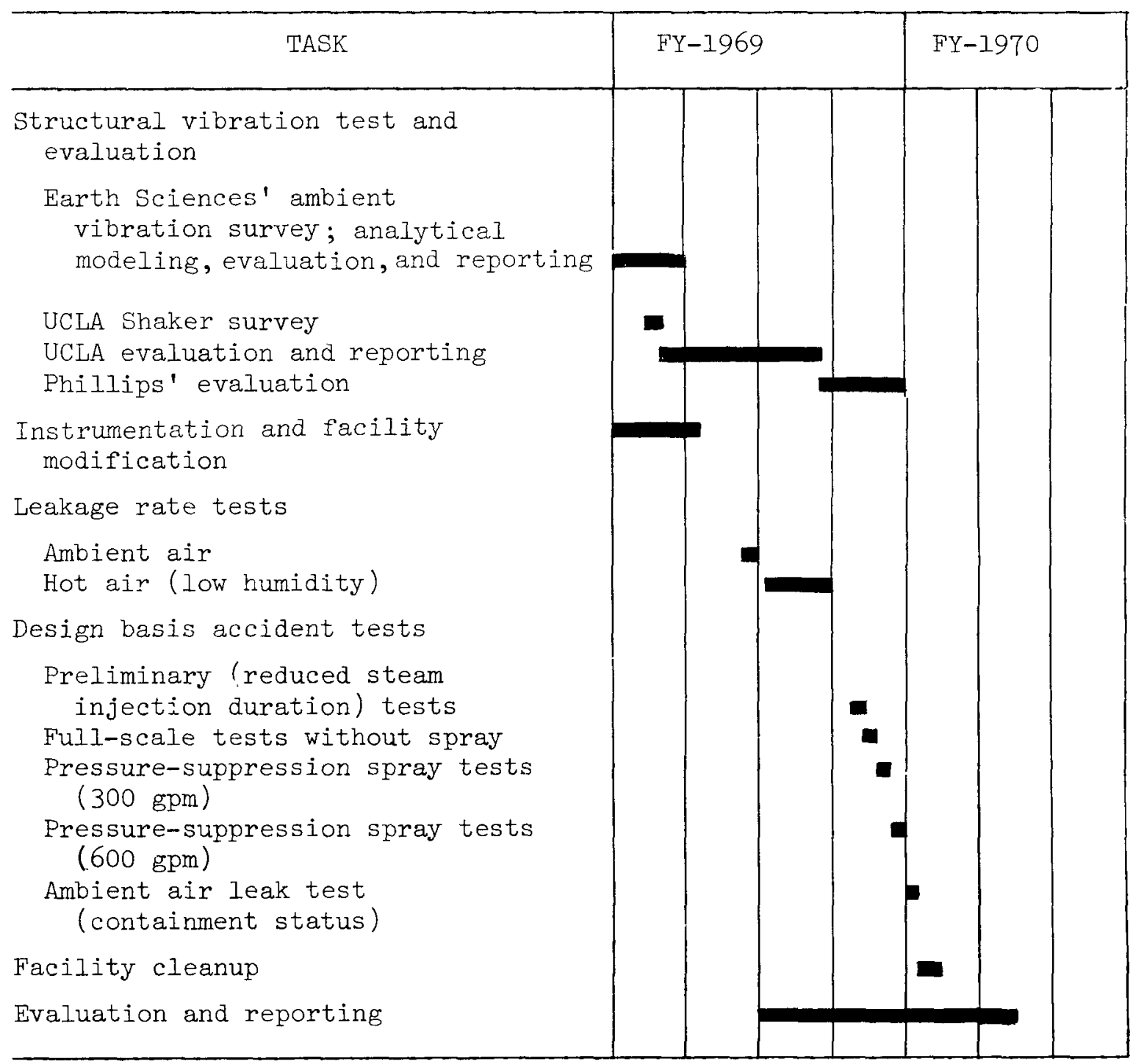




\section{STRUCTURAL VIBRATION TESTS}

Vibration testing of the CVTR containment was performed by two methods: (a) natural (ambient) and (b) shaker (forced) excitation. For the tests, the containment structure was instrumented with accelerometers to record overall vibration behavior. The data obtained is being used to determine the characteristic frequencies, mode shapes, and damping factors of the structure. The shaker tests were performed at several different frequencies and force amplitudes, over the ranges of 0.1 to $50 \mathrm{cps}$ and 0.001 to $0.01 \mathrm{~g}$ acceleration, respectively.

The vibration modes and damping factors obtained from these tests are being compared to results calculated by analytical methods and associated models currently used for dynamic structural designs. Some of the conclusions reashed following these tests are noted under Accomplishments, Section I-3.3.

Comparison of results from the ambient tests and the forced vibration tests remain to be completed.

\section{CONTAINMENT LEAKAGE TESTS}

Tests have been performed to investigate the effects of pressure and temperature on the integrated leakage rate of the CVTR containment and to evaluate leakage measurement instrumentation and techniques. Reduction and evaluation of the results of these tests are currently in progress.

Data from the leakage rate test series performed at several internal pressures in ascending and descending order at DBA temperature will be used to evaluate analytical methods for extrapolating leak rates measured at lower pressures and temperatures (AEC compliance tests) to those expected at higher pressures and temperatures (DBA conditions). The tests have provided data for the evaluation of generally accepted containment leakage rate measurement techniques with respect to accuracy and sensitivity. Insight was gained regarding atmospheric temperature distribution effects on leakage rate measurements. For each test condition, sensitive and accurate instrumentation was used, and comparisons were made between the reference vessel and absolute pressure differential methods of determining containment leakage.

Major sources of measurement error will be evaluated, and recommendations will be made on possible methods of reducing the errors. Statistical and error analysis techniques will be used to evaluate the applicability of the generally assumed, normal distribution functions associated with the analysis of the test data.

An integrated leakage rate test following the DBA tests also will be used to determine changes in the CVTR containment leakage caused by DBA testing.

\subsection{Ambient Air Leakage Rate Tests}

These tests were accomplished by pressurizing the containment with air at ambient temperature and allowing the pressure to decay over a period 
of time. The leakage rate was determined by both the reference vessel method and the absolute pressure measurement method.

Tests were run at 6,13 , and 21 psig in ascending and descending order to determine the relationship between the leakage rates at low and high test pressures. Instrumentation, including several reference systems of different designs, and different types of temperature and pressure measuring equipment were used to evaluate minimum instrument requirements for acceptable results. Test durations were varied to evaluate test time requirements. To prevent perturbation of the leakage rate between tests, each test was performed immediately upon completion of the previous test without shutdown or entrance into the containment system.

\subsection{Hot Alr Leakage Rate Tests}

During leakage rate tests at elevated temperatures, information was obtained on the thermal properties of the CVTR containment system. Heat capacities and steady state heat transfer data such as heat losses and temperature profiles were determined. This information will be useful for comparison with calculated values and can be used as input to typical containment response computer codes such as CONTEMPT.

To evaluate the effect of temperature on containment leakage rate and integrity, the containment was pressurized with air at ambient temperature, and high capacity electric heaters installed in the recirculating air system were used to raise the temperature of the containment atmosphere at constant pressure. The electric heaters were then programmed so that the heat input balanced the heat loss and steady state conditions were established. The following measurements were made during this test:

2.21 Containment Vessel Leakage Rate. Integrated leakage rate measurements similar to those taken at ambient temperature were made at 140 and $200^{\circ} \mathrm{F}$, both at 21 psig. The leakage rates at these conditions will be compared to those of the previous ambient temperature tests at 13 and 21 psig to determine the temperature effect on leakage rate.

2.22 Containment Vessel Strain. Before the high temperature integrated leakage rate testing was initiated, the containment vessel steel liner was instrumented with strain gages. During the initial pressurization in preparation for the high-temperature leakage rate testing, base-point strain measurements were made at ambient temperature and various pressures up to and including 21 psig. Strain measurements also were obtained at several temperatures during the heatup for the hot air leakage rate test.

2.23 Containment Vessel Expansion. In conjunction with the vessel strain measurements, a series of measurements was made to determine the vertical and radial expansion of the containment vessel. These measurements were obtained by positioning special strain gages at various locations on the outside of the containment structures and by theodolite (transit) observations. The measurements provided a history of containment vessel expansion as a function of pressure and temperature of the containment atmosphere up to and including DBA conditions. 


\section{DESIGN BASIS ACCIDENT TESTS}

To determine the effects of DBA conditions on a containment, a series of simulated DBA tests will be performed in CVTR. The specific objectives of these tests are:

(1) To obtain experimental data on pressure and temperature for evaluating the capability of typical computer codes, such as CONTEMPT, to predict the response of a containment atmosphere subjected to DBA conditions

(2) To determine the effectiveness of a pressure-suppression containment spray system

(3) To determine the effects of DBA conditions, exclusive of radiation, on the CVTR containment integrity and on the safety instrumentation and engineered safety systems.

The temperature-pressure history of the CVTR containment atmosphere will be determined experimentally during simulated DBA conditions both with and without pressure reduction sprays. Also, during the tests, time-dependent heat transfer data (including convective behavior) will be obtained at various locations throughout the containment structure, and strain data will be obtained for the steel liner of the containment.

The containment atmosphere response data obtained during these DBA tests will be compared with those calculated by the CONTEMPT computer code for the test conditions. Comparisons will be made between the experimentally determined and predicted heat transfer characteristics and, where necessary, recommendations will be made for improving computer code heat transfer models.

The strain data will aid in evaluating the effects of the DBA testing on the CVTR containment steel liner. Pre- and post-test visual observations and photographic recordings will be made of both the inside and outside of the containment structure to help determine gross effects on the containment integrity caused by the DBA tests. Attempts will be made to evaluate changes in the containment leakage rate during the DBA tests. A controlled leak will be employed throughout the DBA tests for providing a tie to the integrated leakage rate tests. Quantitative evaluation of the overall effects of the DBA testing on the containment leakage rate will be obtained by performing integrated leakage rate measurements in the containment system both before and after the DBA tests.

The DBA tests which will be performed to meet the test objectives are: (a) one test employing steam injection to create the $21 \mathrm{psig}, 215^{\circ} \mathrm{F}$, and $100 \%$ humidity conditions followed by natural pressure decay; that is, without the use of a spray pressure reduction system and (b) two steam tests for these conditions but using two spray pressure reduction system flow rates. In addition to the steam tests, some limited operational demonstration tests will be conducted for the CVTR engineered safety systems and key safety equipment. 


\subsection{Steam Test -- Natural Pressure Decay}

The initial simulated DBA steam test will be performed by rapidly bringing the containment atmosphere to DBA pressure conditions (21 psig) with steam, shutting off the steam flow, and allowing the containment atmosphere to return to ambient conditions by natural decay. The pressure-temperature history of the containment atmosphere will be measured and data obtained will be compared with predictions calculated by the CONTEMPT code. Photographic records of condensation and convective flow behavior and measurements for flow distribution, temperature stratification, temperature profiles near and in the containment wall, and heat flux at the surface of selected heat conducting structures will be made in an effort to define the containment heat transfer characteristics. Additionally, other evaluations will include leakage through a controlled leak path, gross containment leakage, vessel strain and expansion behavior, and the effect of DBA conditions on equipment and safety system operation.

\subsection{Steam Tests -- Spray Pressure Reduction}

Two simulated DBA steam tests will be performed to determine the containment response to, and the effectiveness of, a containment pressure reduction spray system. Examination of the safety analysis reports for current PWR and BWR systems has indicated that containment spray systems vary considerably in design. For example, of four systems examined, flow rates varied from 500 to 4000 gallons per minute. Thus, two pressure reduction spray tests using spray flow rates which differ by a factor of two will be performed to evaluate the effect of spray flow rate on containment pressure reduction.

These tests will be performed by using steam to bring the containment atmosphere to DBA conditions. The spray system will be actuated and measurements will be made of the pressure and temperature histories of the containment atmosphere. The experimental pressure and temperature data will be used for comparison with and evaluation of analytical predictions for the effect of spray. Particular attention will be assigned to temperature stratification and how this stratification may affect heat transfer during use of sprays.

\subsection{System Operational Demonstration Tests}

The capability of engineered safety systems and key safety equipment components such as valves, switches, pumps, instrument sensors, and readout equipment to function properly in a DBA environment is important to the safety assessment of a power reactor. In particular, after a DBA, an accurate knowledge of the reactor condition is required before proper action can be taken.

Testing of the CVTR engineered safety systems and key safety equipment under DBA environmental conditions was originally a part of this project but has been reduced in scope by funding limitations. Nevertheless, operability tests under DBA conditions of a few equipment items such as motors, wiring, and switches have been retained where essentially no modifications or additional expenditures are required. Because of these limitations, the data and information obtained from this portion of the CVTR test project will be primarily of a qualitative nature.

Pre- and post-test visual inspection and photographs for reference and documentation will be obtained of the systems and components being investigated. 
Operational failures induced by the DBA environment will be noted and reasons for failure, if known, recorded. Additionally, systems and individual components that successfully operate during the testing will be identified. The report of the findings from this investigation will include a description of the system and component tested and the environmental conditions under which the equipment was operated. 


\section{FACILITY AND EQUIPMENT}

The CVTR facility, owned by the Carolinas Virginia Nuclear Power Associates, Inc. (CVNPA), a corporation formed by four Carolina area private utilities, included a power demonstration prototype of a full-scale, heavy water-moderated and -cooled, pressure tube reactor. The plant, located about 25 air miles northwest of Columbia, South Carolina, is adjacent to the Parr Station of the South Carolina Gas and Electric Company.

CVTR went critical in March 1963 and began power operation in December 1963. Nuclear power operation was terminated in February 1967, and decommissioning of the facility was essentially complete by December 1967.

\section{FACILITY DESCRIPTION}

The portions of the CVTR facility of interest to the in-plant testing program, including the containment system and associated equipment necessary to perform the test program, are described in the following sections. The reactor system, which is not of direct interest to this testing effort, is not discussed. A description of the CVTR facility is contained in CVNA-90, Final Hazards Summary Report [5].

\subsection{CVTR Containment System}

The CVTR vapor container is a reinforced concrete, right vertical cylindrical structure with a flat base and hemispherical dome. The container, shown in Figure 1, has a 58-foot $O D$ and is about 114-feet high inside. It has a 2-foot-thick reinforced concrete cylindrical wall which supports a 1/2inch-thick steel dome covered by $20-1 / 2$ inches of concrete. The container has a 5-foot 9-inch-thick reinforced concrete foundation mat, the bottom of which is about 59 feet below ground level. The top of the foundation mat and the vertical cylindrical wall are lined with $1 / 4$-inch-thick steel plates to make the container vapor tight. A 13-foot-diameter circular equipment hatch with a personnel door and a 2-foot 9-inch-diameter circular escape hatch are provided for access into the containment. The containment structure houses the reactor, primary system, and the steam generator as well as various auxiliary systems and components.

The containment structure is designed to withstand the occurrence of the CVTR postulated design basis accident. This accident is a sudden rupture of the primary system and includes the energy released from a reaction of $35 \%$ of the Zircaloy cladding with heavy water and a one million Btu nuclear excursion. The combined energy releases result in the calculated design accident conditions for the containment of approximately 21 psig at a temperature of $215^{\circ} \mathrm{F}$. The containment structure was tested to 26 psig following construction of the CVTR facility.

\subsection{Steam Supply System}

Steam for simulating DBA conditions in the containment will be supplied from the Parr Station. During reactor operations, steam generated at the 


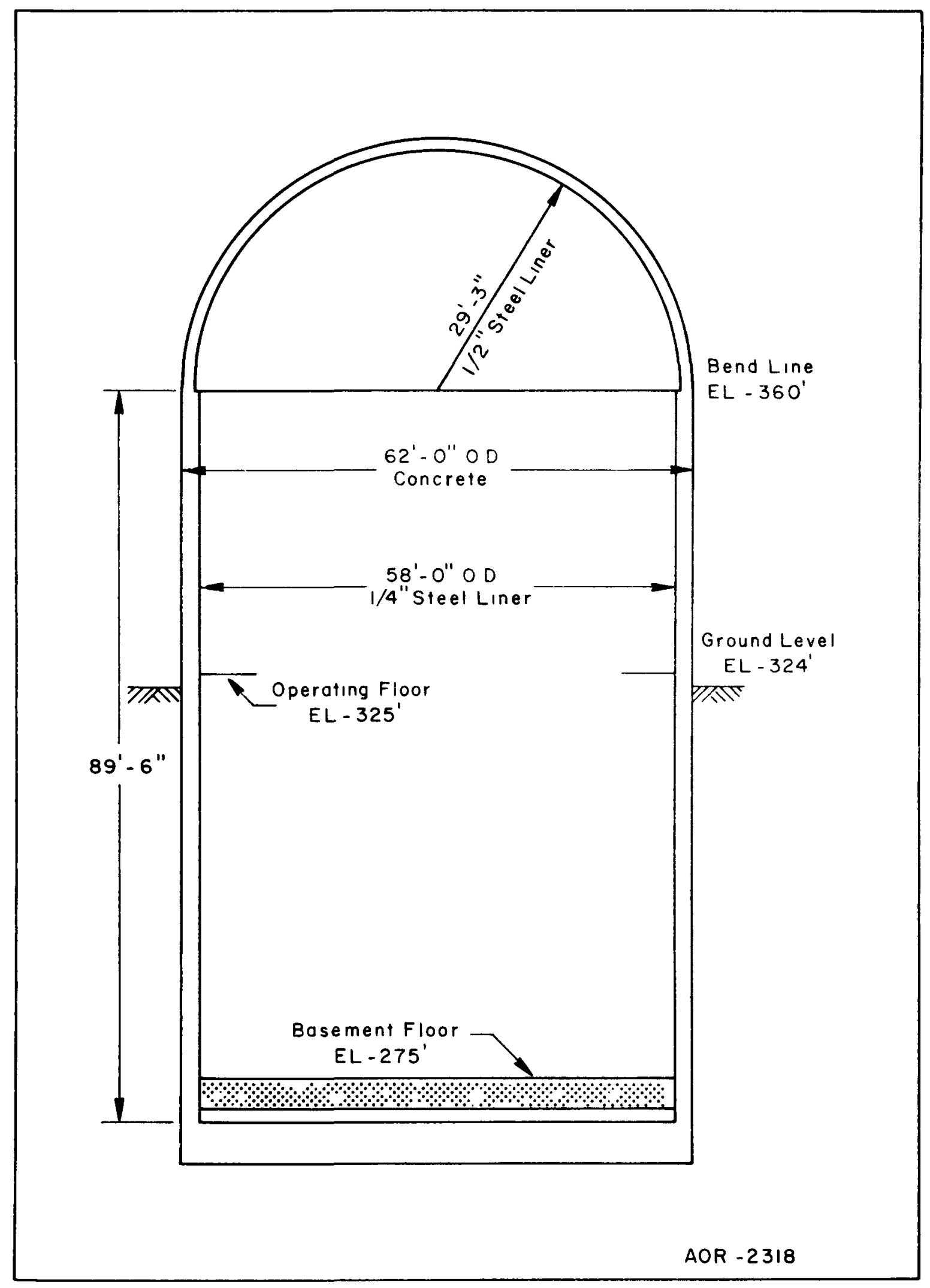

Fig. 1 CVTR containment structure. 
CVTR was supplied to the Parr Station header through a 10-inch steam line. This line has been modified to permit steam flow in the reverse direction from the Parr Station to the CVTR containment. The boiler capacity of the Parr Station for this type of service is approximately $350,000 \mathrm{lb} / \mathrm{hr}$ steam flow at 400 psig and $725^{\circ} \mathrm{F}$.

The major modifications to the existing steam line to permit the desired service included by-passing the oil-fired CVTR superheater, installing cylinder-operated steam control valves, installing a desuperheater, cutting the steam line inside the containment and installing additional instrumentation and steam line supports. A schematic diagram of the steam addition system is shown in Figure 2 .

The desuperheater was installed in the steam line to bring the steam quality nearly to saturation prior to steam injection into the containment. Full steam flow will be established to the outside atmosphere near the containment then rapidly switched into the containment, thereby allowing the containment to reach the desired DBA pressure. Then steam flow will be switched rapidly back to the outside atmosphere and the steam plant will be shut down. Automatically or manually (or both) controlled cylinder-operated steam valves will direct the steam flow.

Safety features for the prevention of containment over-pressurization include a diaphragm operated block valve actuated by containment pressure or manual override, hand-operated block valves, and a 30-inch rupture disc assembly installed in the containment emergency personnel escape hatch. The rupture disc was designed and tested for release at 25 psig $\pm 10 \%$.

\subsection{Containment Pressure Reduction Spray System}

A containment pressure reduction spray system patterned after the Connecticut Yankee spray system has been installed in the CVTR containment. The spray system is designed to provide two flow rates, 300 and 600 gallons per minute, approximately. The spray nozzles, which were selected to produce droplets ranging from approximately 400 to 1400 microns in size, are patterned for equal distribution of the water across the containment cross section. Figure 3 is a schematic diagram of the containment pressure reduction spray system.

\subsection{Hot Air System}

To heat the dry containment atmosphere to approximately $200^{\circ} \mathrm{F}$, a bank of electric duct-heaters providing a total of $855 \mathrm{~kW}$ was installed in the air recirculating system. The fan motors for the air circulating system were replaced with larger motors to obtain approximately $25,000 \mathrm{cfm}$ air flow at 21 psig. The containment atmosphere heatup time with this system is estimated to be about 24 hours. A schematic of the hot air system is shown in Figure 4.

\subsection{Controlled Leak Systems}

Two controlled leak systems are installed. One system, shown in Figure 5 , has been used in previous leakage rate testing at CVTR. The other, shown in Figure 6, is used in the integrated leakage rate tests and the DBA tests to provide a common reference for all of the tests. 


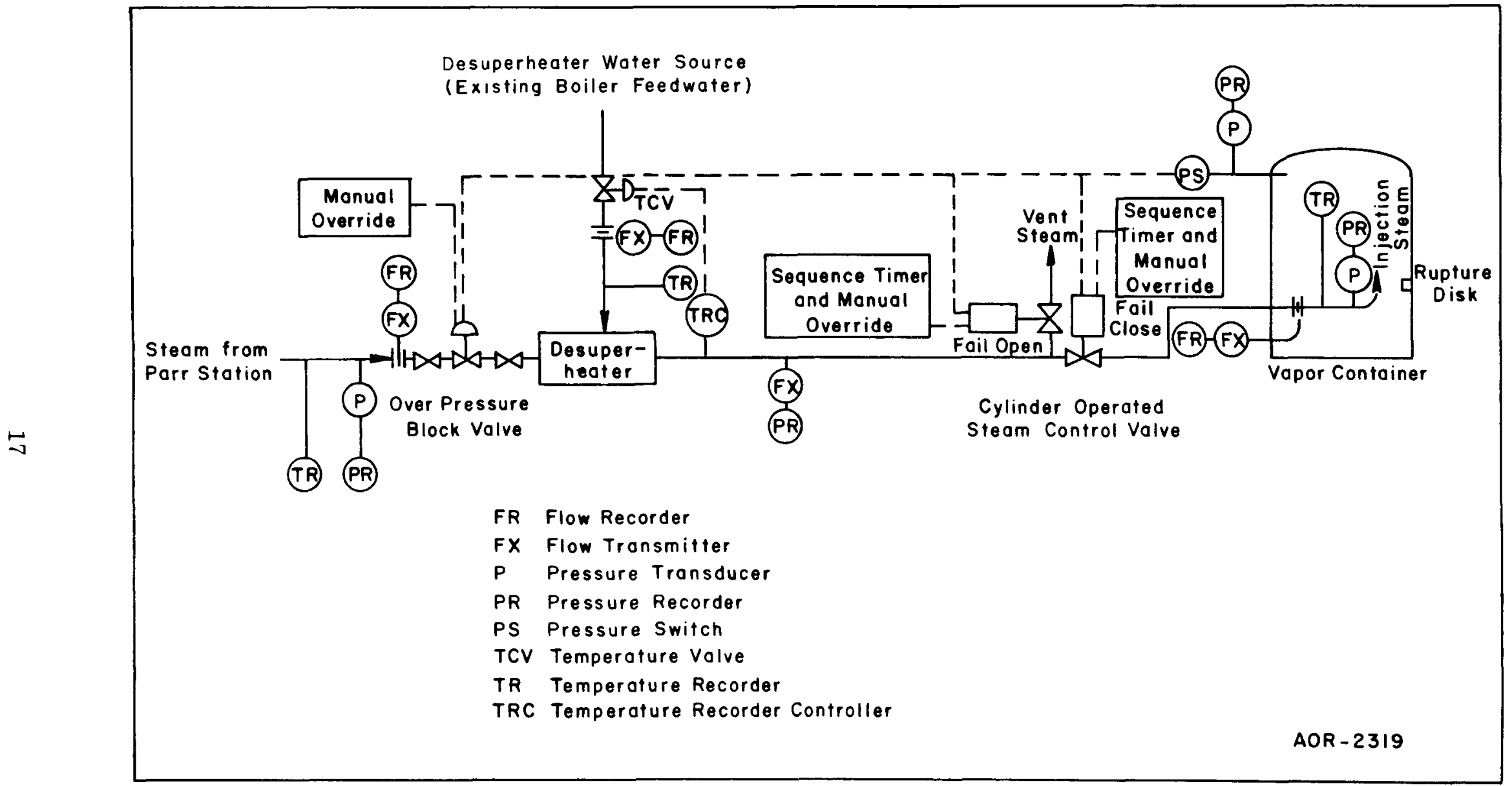

Fig. 2 CVTR steam addition system. 


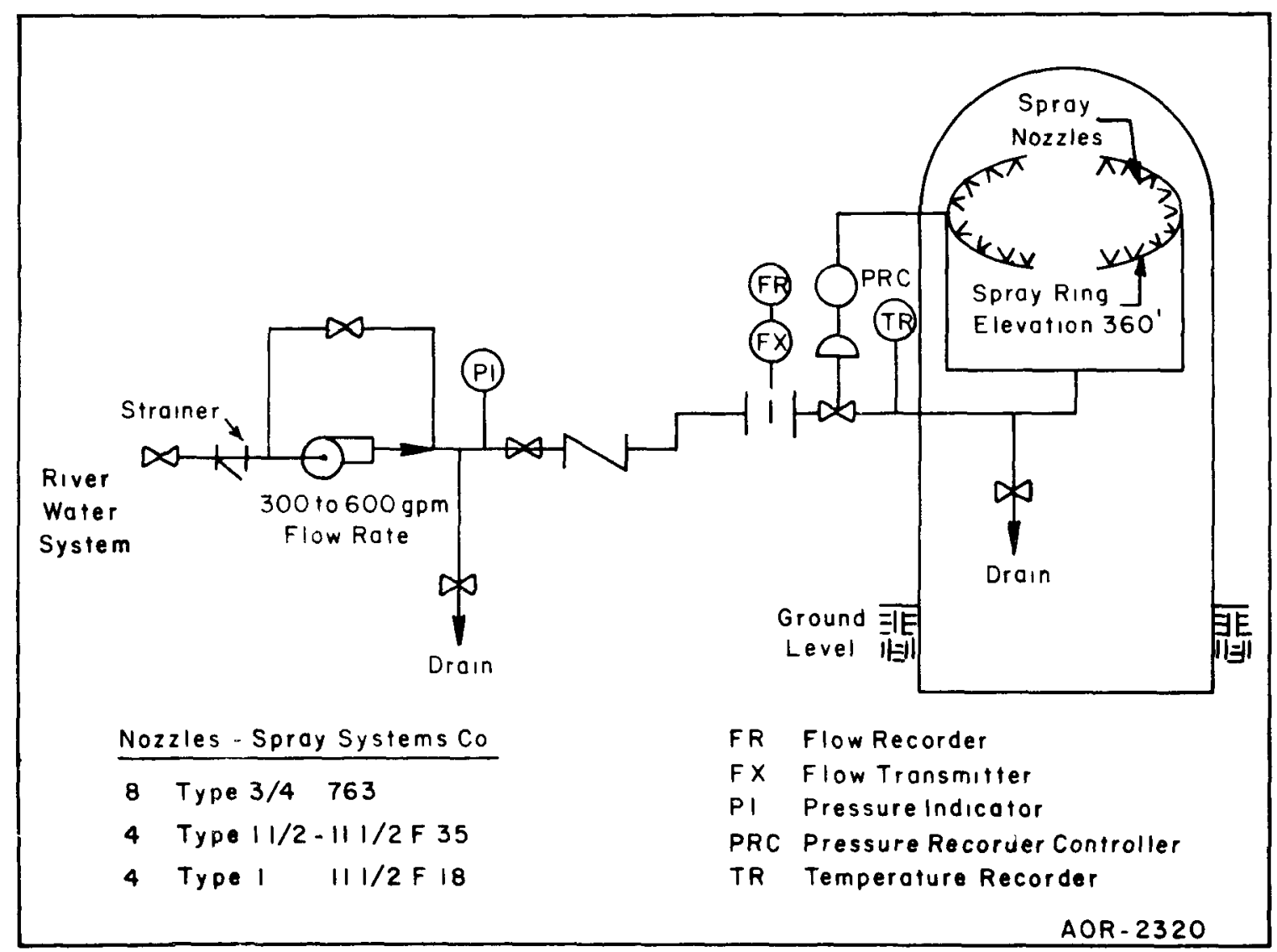

Fig. 3 CVTR pressure reduction spray system. 


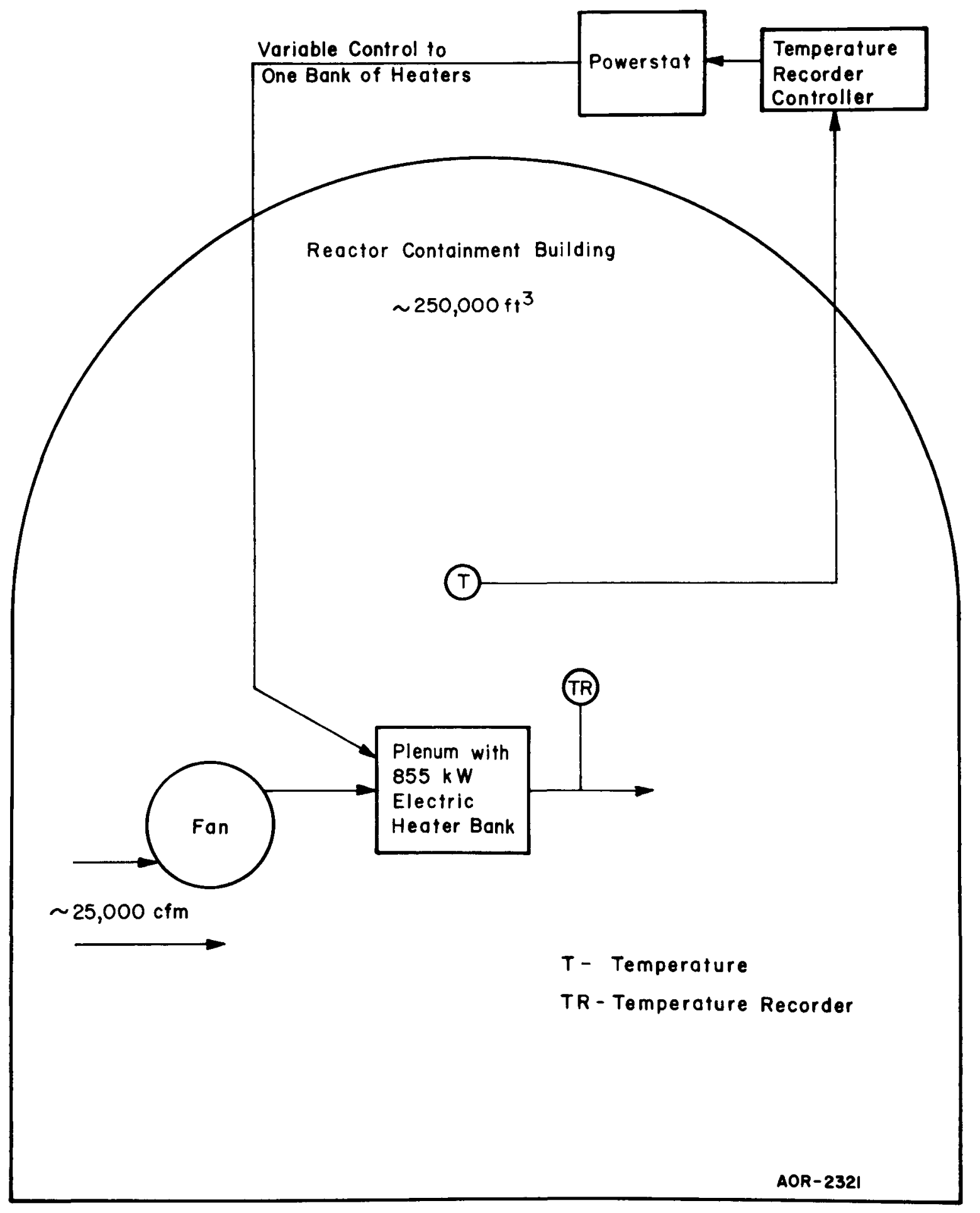

Fig. 4 CVTR hot air system. 


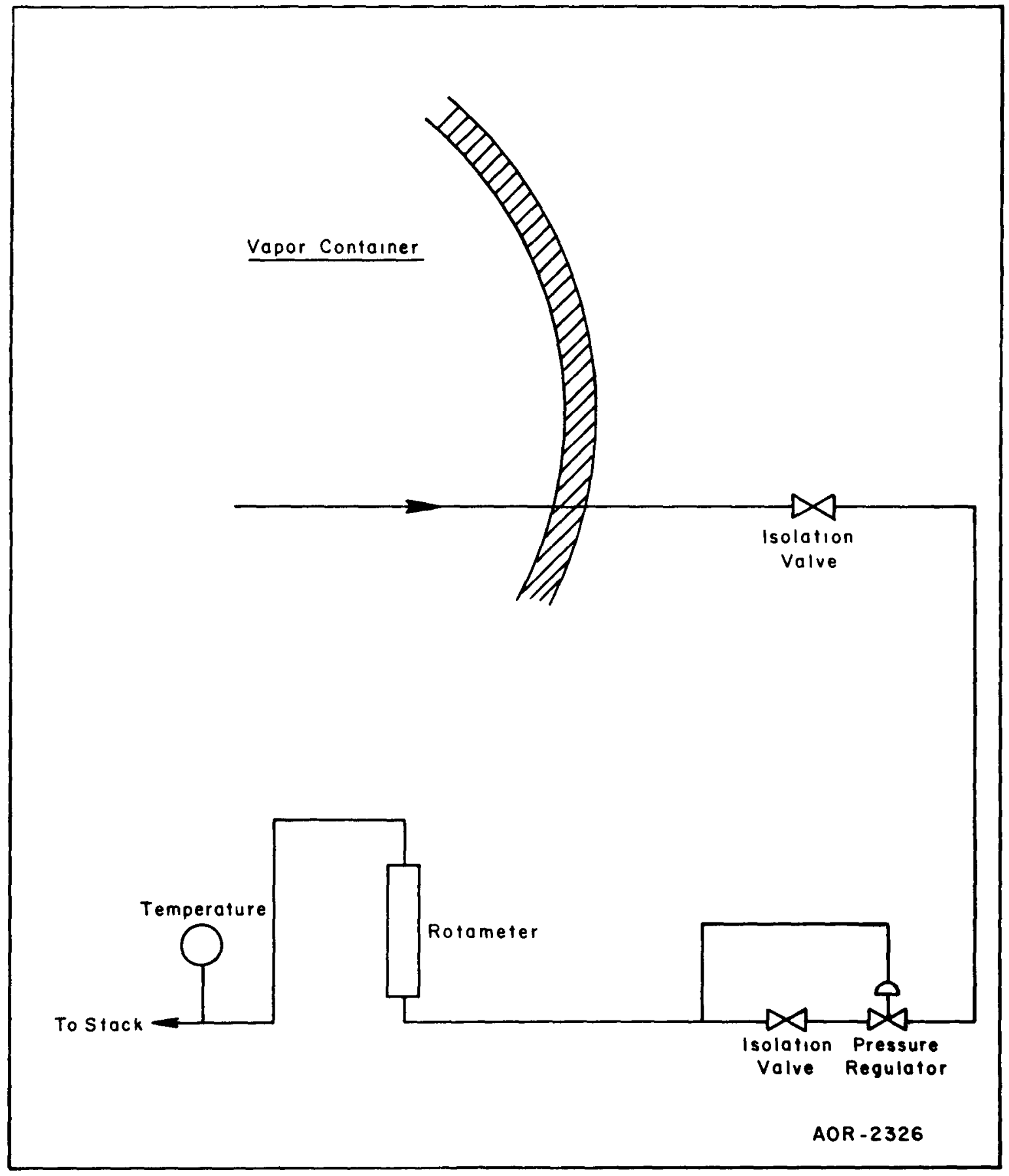

Fig, 5 Controlled leak system used for preliminary tests. 


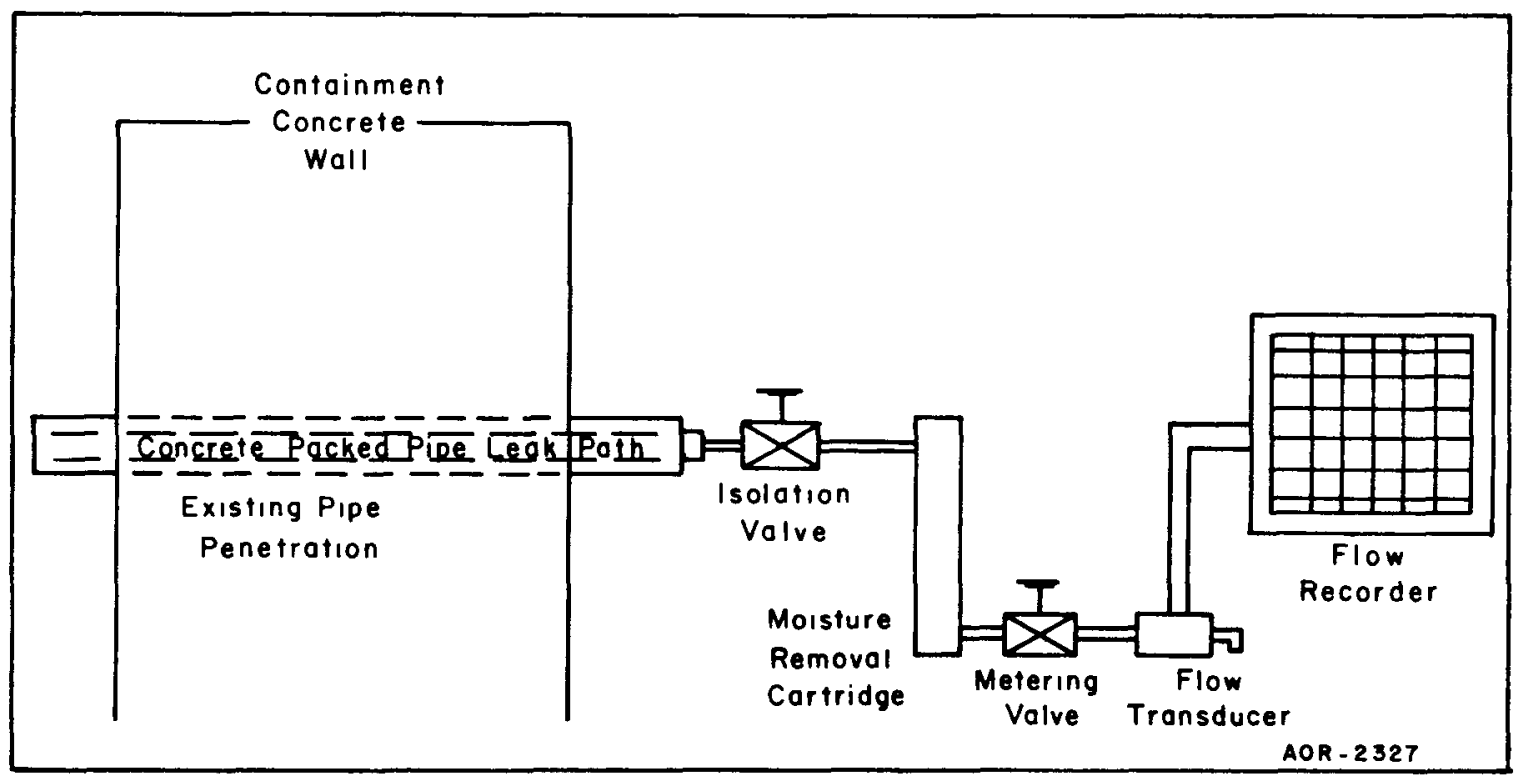

Fig. 6 Controlied leak system used for integrated leakage tests and D B A tests.

\section{MEASUREMENTS}

This section presents a brief description of measurements and measurement systems required for the leakage rate tests, DBA steam tests, and simulated seismic vibration tests.

\subsection{Measurements for Containment Leakage Tests}

Containment atmosphere temperature, pressure, and humidity were the primary measurements made during leakage tests. Both the reference chamber and absolute pressure methods were used to determine leakage rate.

2.11 Reference Chamber Pressure Measurement. The CVTR normally had two parallel reference chambers installed; a 1-inch copper tube system and a 1/4-inch copper tube system; however, neither of these systems was installed on a volume-weighted basis. Two additional reference chamber systems were installed on a volume-weighted basis; that is, the volume of the reference chamber was proportionately distributed throughout the containment volume. These chambers, one of which is shown in Figure 7 , are constructed of $3 / 4$-inch thinwalled copper tubing.

2.12 Absolute and Differential Pressure Measurements. Absolute and differential pressure measurements were made during the integrated leakage rate tests. Differential pressures between the containment atmosphere and the 3/4inch reference chambers were measured with precision Bourdon tubes and a water micromanometer. Precision Bourdon tubes were also used to measure the absolute pressure of the containment atmosphere and the absolute pressure of the reference chamber. Figure 8 is a schematic of these systems. 


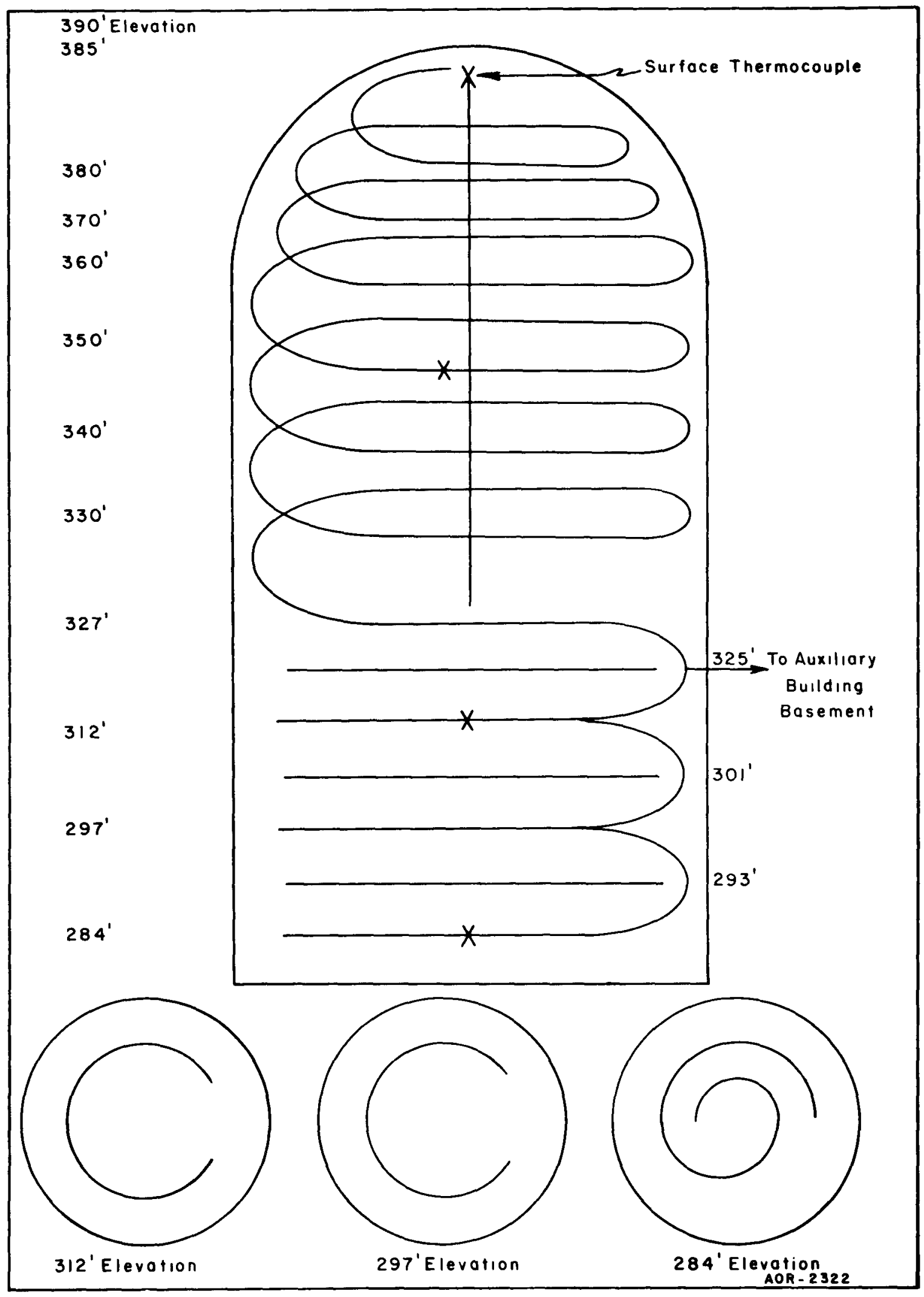

Fig. 7 Reference vessel system. 


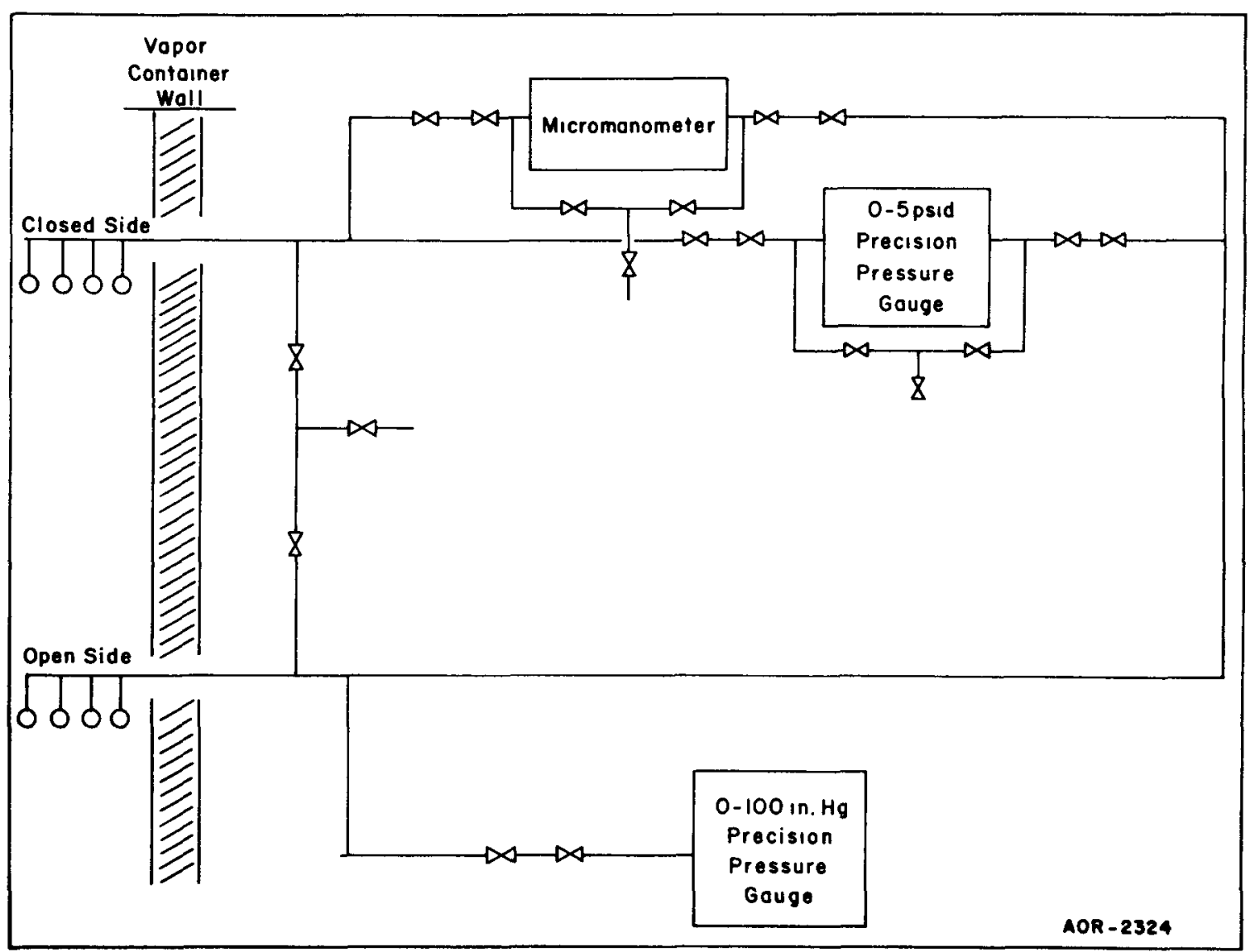

Fig. 8 Absolute and differential pressure measuring system.

The existing CVTR leakage rate pressure measuring systems also were used. These systems included the two reference chambers with Zimmerli gages for measuring the differential pressure between the CVTR reference chambers and the containment atmosphere. Manometers were used to measure the absolute pressure of the containment atmosphere and the barometric pressures.

2.13 Atmospheric Temperature Measurements.Temperature measurements of the containment atmosphere were made with 29 shielded and calibrated thermocouples and 15 calibrated resistance bulb thermometers. The temperature measuring devices were positioned throughout the containment air volume to provide a volume-weighted temperature measurement.

In-place calibration of each detector and associated readout system was made by reference to a quartz-crystal thermometer with $\pm 0.01^{\circ} \mathrm{C}$ accuracy traceable to the National Bureau of Standards. The accuracy of the temperature measuring systems was statistically determined from the calibration data.A special computer program was used for this analysis.

2.14 Surface Temperature Measurements. Surface temperature measurements of the reference chamber system and the interior of the containment structure were made with thermocouples. Four thermocouples were attached 
to the reference chamber and nine thermocouples were attached to the containment surfaces. Calibration of these thermocouples for these measurements was similar to that employed for the atmospheric temperature measurements.

Figure 9 is a schematic of the temperature measuring system for the integrated leakage rate tests.

2.15 Humidity Measurements. The humidity of the containment atmosphere was measured with a dewpoint hygrometer. Figure 10 is a schematic diagram of the measurement system. As noted from the figure, the average humidity of the containment atmosphere was determined, and the humidity of the air at specific elevations was obtained.

2.16 Containment Steel Liner Strain Measurements. Strain measurements of the steel liner were made at 78 locations with three-gage rosettes. These gages are capable of operation in a steam environment and will be used for strain measurements during the DBA steam tests. Laboratory calibrations of typical gage installations were made. Readout of the gages during the CVTR tests is accomplished with the data acquisition system described in Section IV.3.

2.17 Containment Structure Expansion Measurements. Vertical and circumferential expansion of the containment structure was determined during the integrated leakage rate testing at constant pressure. These measurements were made by readout of several large strain gages attached to the outside of the containment structure and by visual observations by using surveyor's transits and scales attached to the outside of the containment. The containment expansion measurements at increased pressure are being compared with the temperature expansion measurements.

2.18 Heat Transfer Measurements. In addition to the containment atmosphere and surface temperature measurements, temperature profiles through the containment wall were obtained during the hot air leakage tests. Special heat transfer assemblies were installed at selected locations in the containment wall. The primary purpose of these devices is to measure the condensation heat transfer at the inside surface of the containment during the DBA steam tests; however, the assemblies also will be used to determine the steady state heat conduction through the containment walls. Thermopile-type heat flux gages on the surface of the liner also are used for a similar purpose. A detailed description of this apparatus is given in the following section on DBA steam testing.

\subsection{Measurements for DBA Steam Tests}

The measurements of primary interest during the DBA steam tests are the temperature and pressure histories of the containment atmosphere as functions of the steam injection rate and flow rate of the containment pressure reduction spray. Other measurements of interest include the condensation heat transfer at the containment surfaces and the containment steel liner strain. Other information will be obtained, including the controlled leakage, gross changes in containment leakage, containment integrity, and environmental effects on equipment operation. Methods for obtaining the latter information have been discussed in previous sections. 


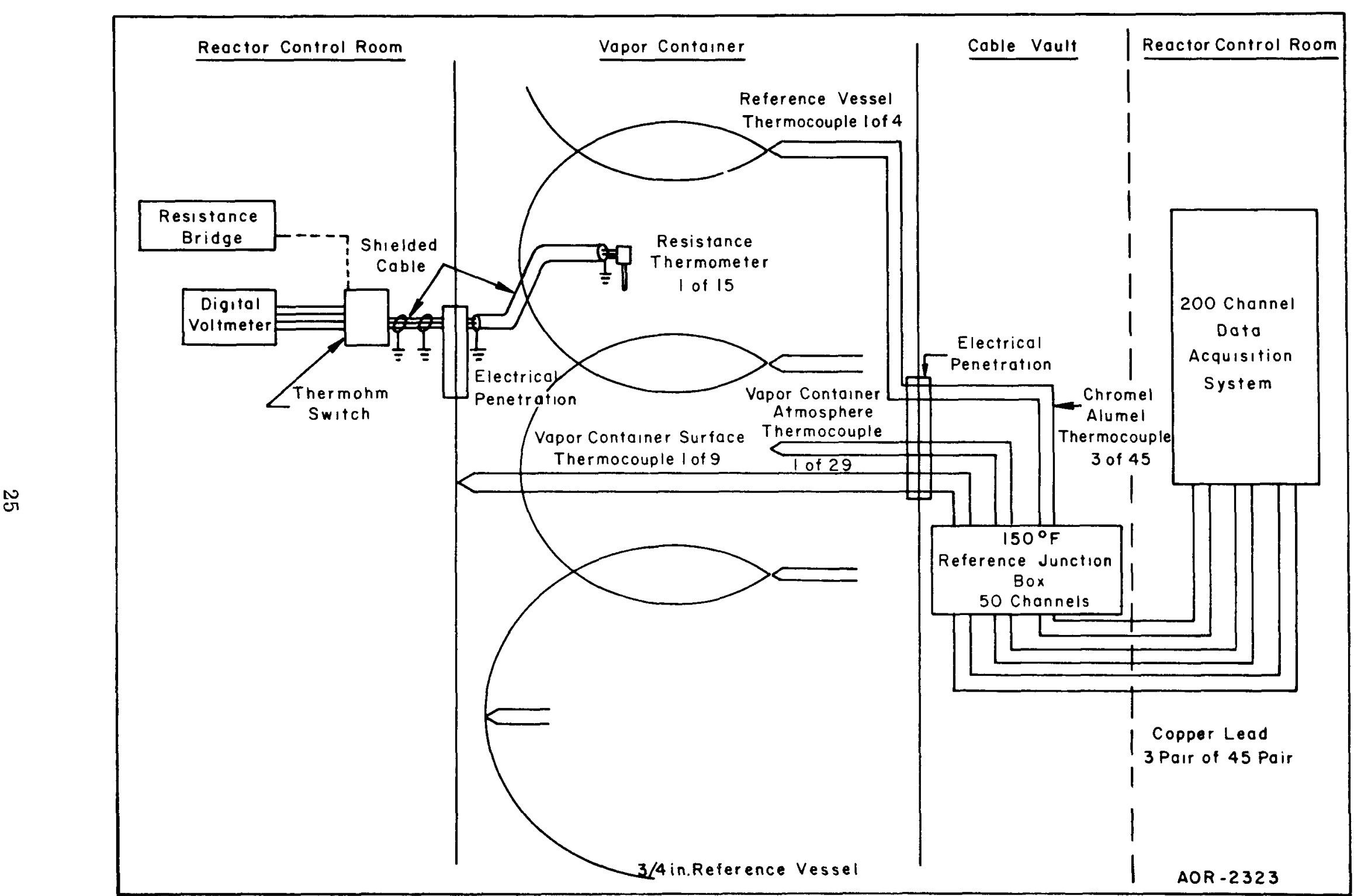

Fig. 9 Surface temperature measuring system. 


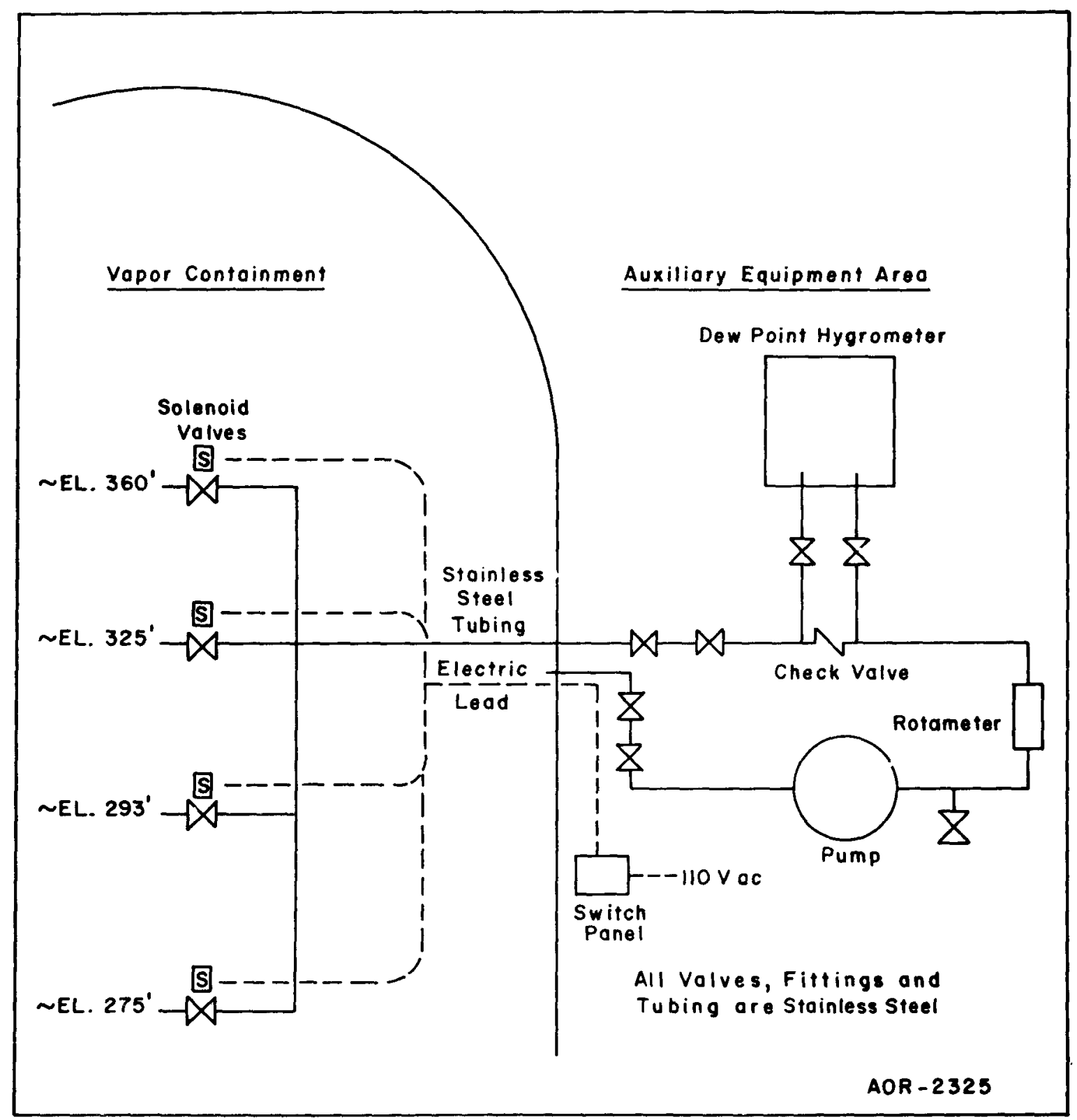

Fig. 10 Containment vessel humidity measuring system.

2.21 Containment Atmosphere Temperature and Pressure Measurements. A primary objective of the CVTR DBA steam tests is to obtain measurements of the containment response to a DBA and to relate this experimental response to that calculated by current analytical techniques. Since the DBA steam tests exhibit basically transient phenomena, time-dependent measurements of the desired parameters are a requirement.

The fast response time-dependent temperature of the containment atmosphere will be measured by the same thermocouples that were installed for air temperature measurements during the integrated leakage rate tests. Air temperature data also will be obtained from the resistance bulb thermometers; however, the time response of these devices is much slower than that 
of the thermocouples, and they will be used mainly for spot checking the air temperature during times of less rapidly changing conditions. Readout of these temperature detectors will be accomplished on the data acquisition system described in Section IV.3.

The time-dependent pressure response of the containment atmosphere will be measured with five 0 to 50 psig fast-response pressure transducers. Four of the transducers will be located at various elevations within the containment, and the fifth will be positioned in a pipe which is open to the containment atmosphere. Figure 11 is a schematic diagram of the transient-pressure measuring system.

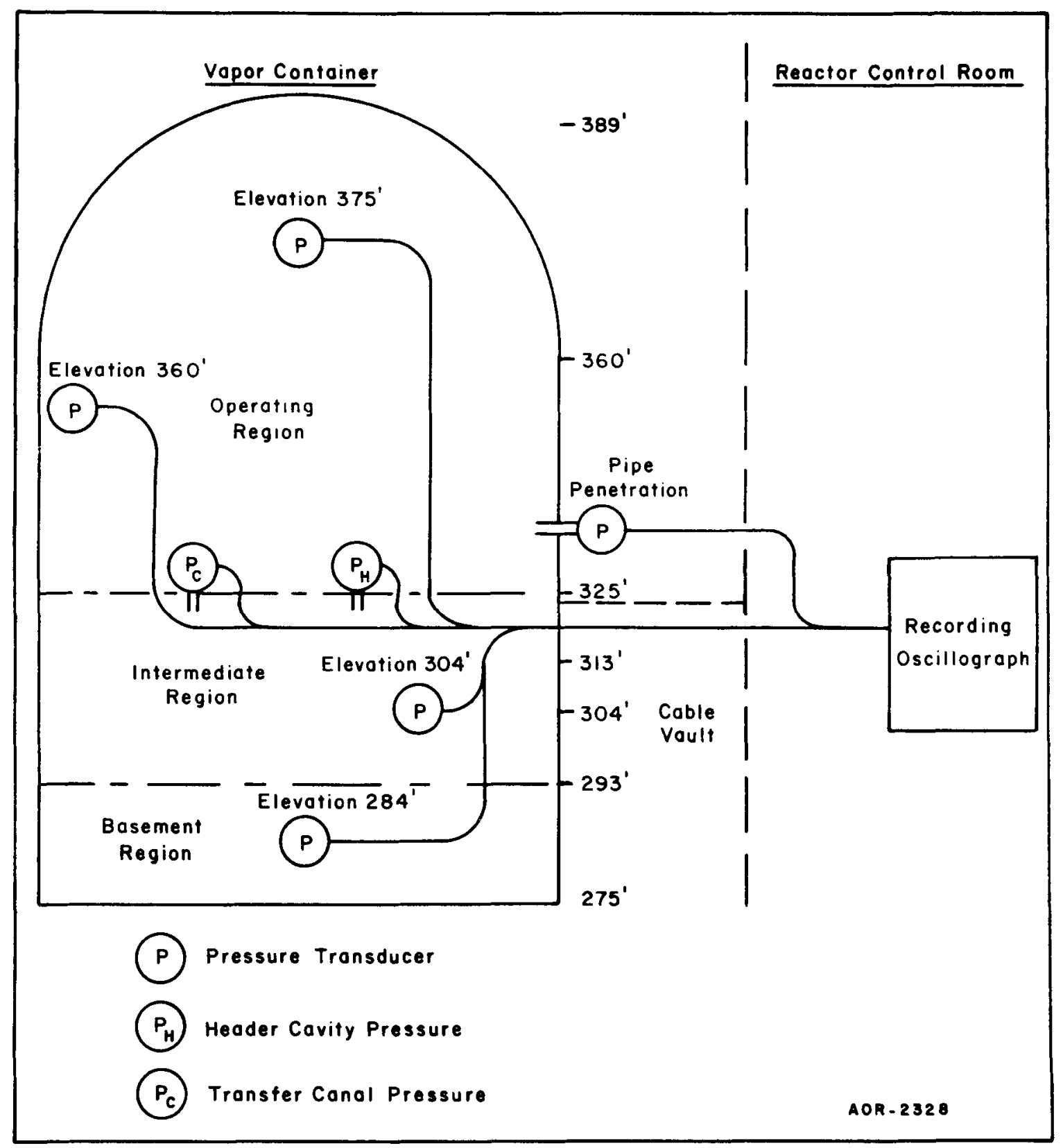

Fig. 11 Transient pressure measuring system. 
2.22 Condensation Heat Transfer Measurements. The condensation heat transfer rate at several locations on the containment steel liner will be determined. During the DBA steam tests, time-dependent measurements will be made of: (a) the temperature profile through the containment wall, (b) the heat flux into the wall, (c) the condensate collected from various containment wall areas, and (d) the gross convective current behavior in the containment. The data from these measurements, in conjunction with other DBA test data, will be analyzed by computer techniques to arrive at the condensation heat transfer rate at the surface of the containment steel liner. Figures 12 and 13 are schematic diagrams of the temperature profile measuring scheme and the condensate rate gage system, respectively.

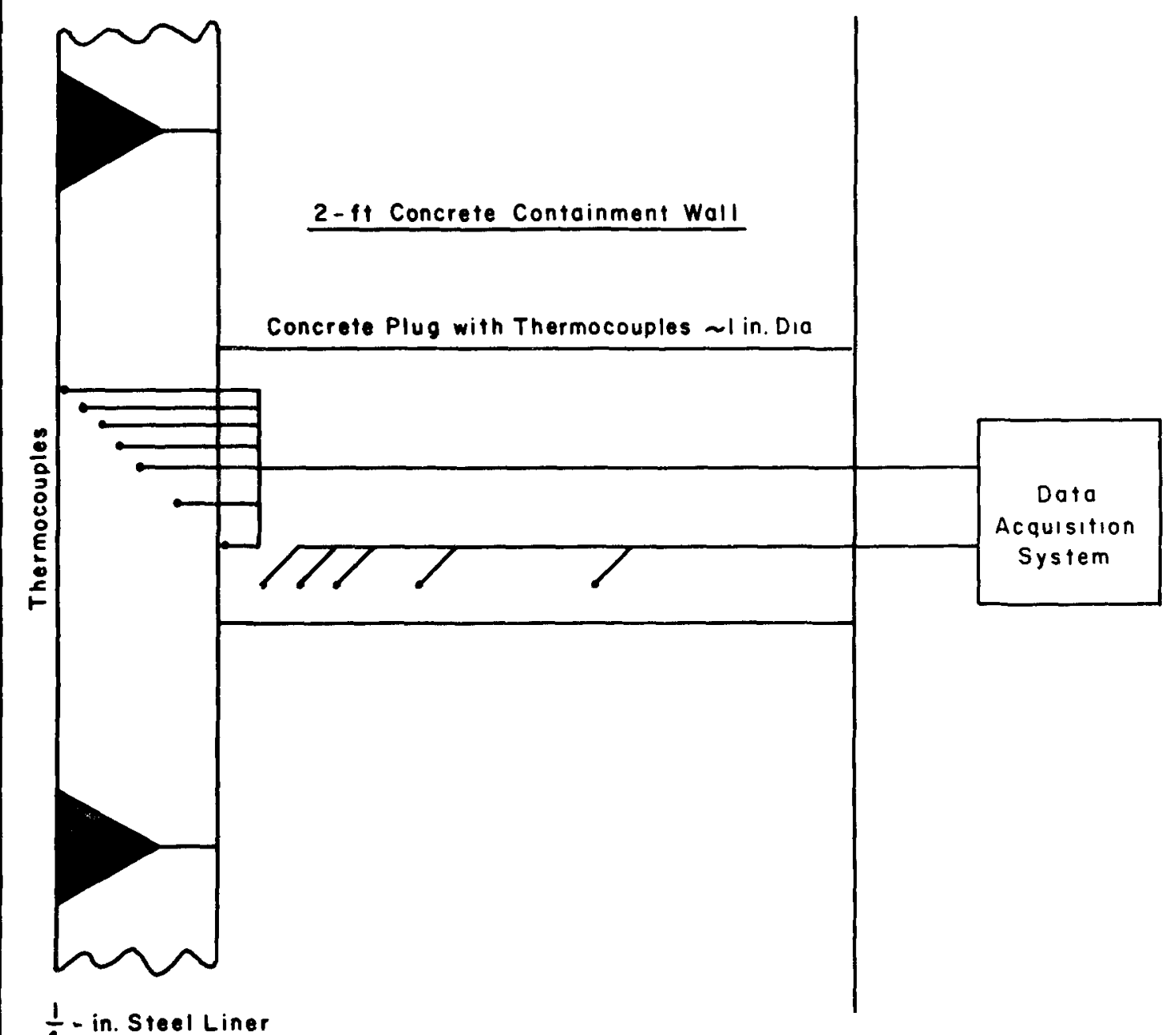

AOR - 2329

Fig. 12 Temperature profile measuring system. 


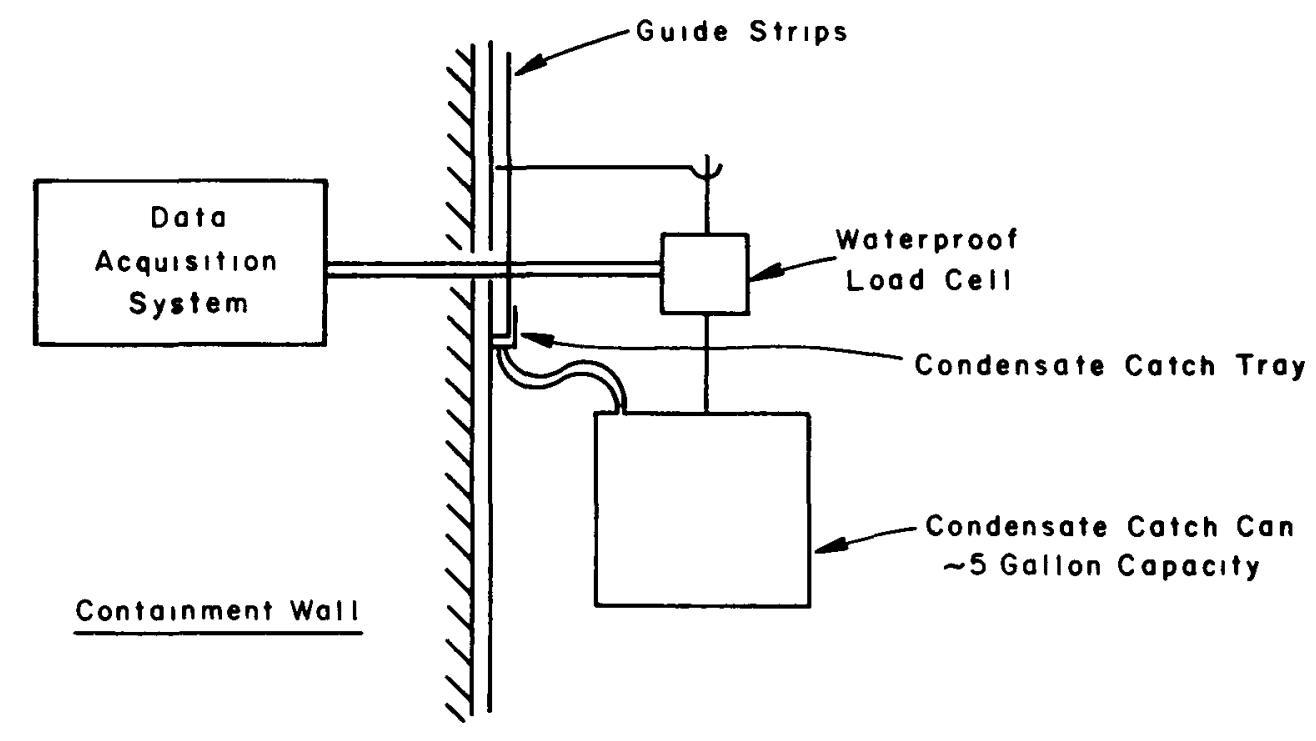

Typicol Cotch Can Assembly

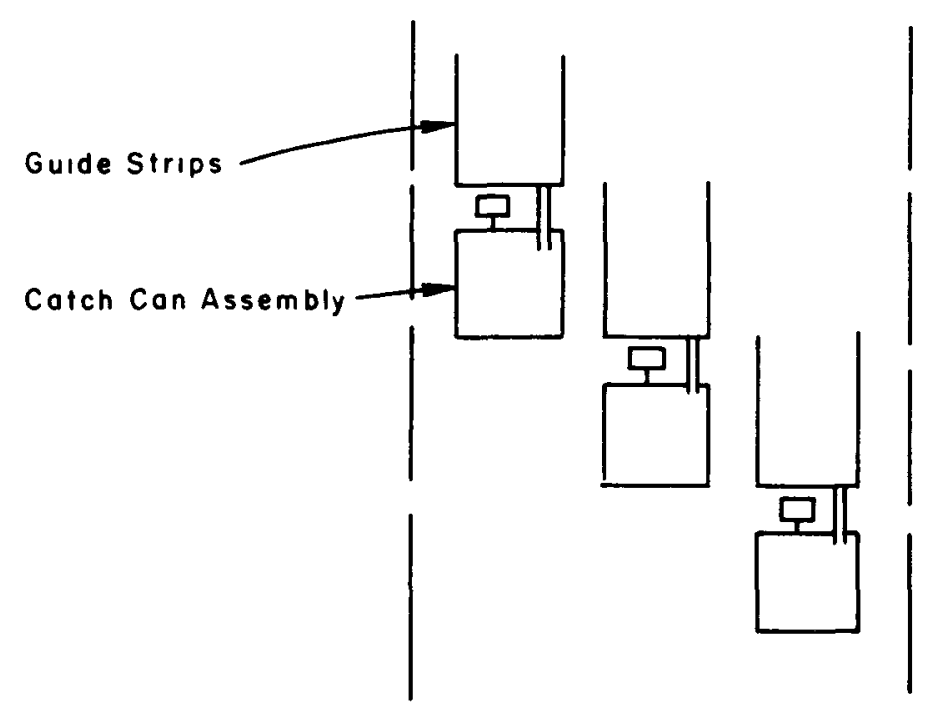

Typical Cafch Con Arrangement

On Containment

Steel Liner Surface

Fig. 13 Condensation rate gage system. 
2.23 Containment Steel Liner Strain. The strain gages used during the hot air integrated leakage rate tests wiil be used to measure the containment steel liner strain during the DBA tests.

\subsection{Measurements for Structural Vibration Tests}

Generally, the measurements made during the vibration tests were obtained with portable seismometers and associated readout equipment. Vibration response measurements were taken at various locations outside and inside the containment structure to determine the dynamic characteristics of the structure. Both translational and torsional modes of vibration were measured. Also, measurements were made in an attempt to determine the coupling action between the soil and the containment structure.

\section{3، DATA ACQUISITION SYSTEMS}

The data acquisition equipment for the CVTR tests includes, but is not necessarily limited to, the following: a digital data acquisition system (slow scan), an analog data multiplexing system (fast scan), a recording oscillograph system, and a digital voltmeter with digital printer.

\subsection{Digital Data Acquisition System (Slow Scan)}

The digital data acquisition system provides the capabilities for scanning and recording data from 198 channels of low level dc signals. These signals may be those of strain gage bridges or the outputs of suitable transducers. Figure 14 hows a functional block diagram of the digital data acquisition system. The outputs from the transducers or the strain gage bridges are sequentially scanned, and the analog outputs are converted to digital form by a digital vcitmeter. A visual digital display of the input signal is provided by the voltmeter which also provides an output to the digital recorder (paper-tape printer) or to a paper-tape perforator or to both. A time code generator is connected to the system so that time (hours, minutes, and seconds) is digitally recorded at the beginning of each scan cycle. The system has the capability of scanning and recording approximately one input signal per second.

\subsection{Analog Data Multiplexing System (Fast Scan)}

The analog data multiplexing system provides the capabilities for scanning, conditioning, and recording up to 100 analog input signals. Each signal is processed approximately three times per second. Figure 15 is a simplified block diagram of the analog data multiplexer. Low voltage level analog signals can be patched into the system as desired. The input signals are multiplexed in groups of 10. Each of the 10 multiplexer outputs is conditioned by a separate low-level driver amplifier. The amplified outputs are recorded on 10 channels of a 14 channel magnetic tape recorder. One channel of the magnetic tape is used for channel Identification and time synchronization of the multiplexer inputs. The remaining three magnetic tape recorder channels also may be used for recording data. These data however, are not multiplexed and, therefore, only one input signal is recorded per channel. 


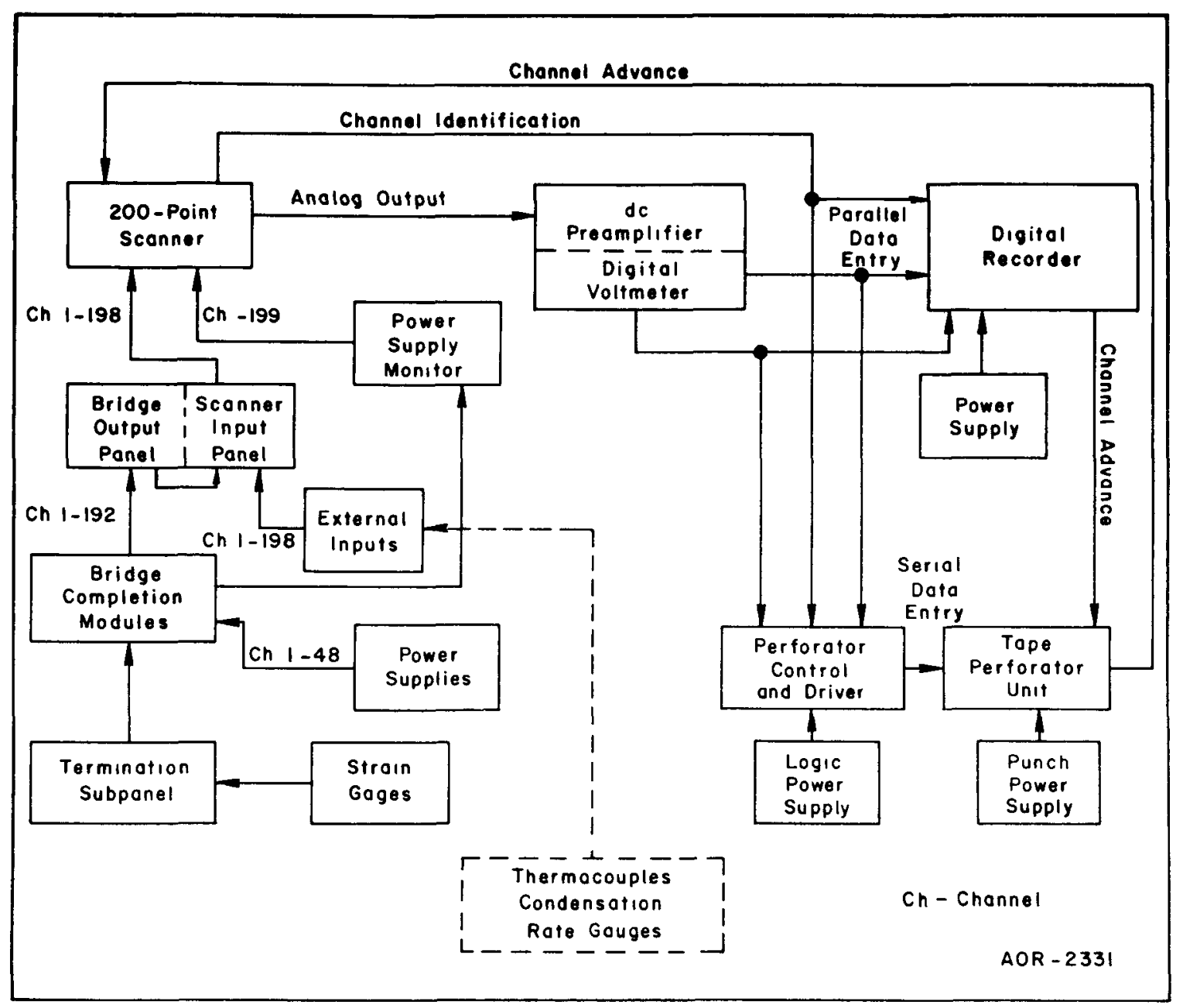

Fig. 14 Digital data acquisition system.

\subsection{Recording Oscillograph System}

The recording oscillograph system provides the capabilities for signal conditioning and continuous recording of up to 36 channels of low voltage level signals. Figure 16 is a block diagram of the recording oscillograph system. Low voltage level signals from suitable transducers are connected to the input terminals. These signals are amplified by the low-level dc amplifiers (which also provide galvanometer protection) and fed into the recording oscillograph. The recording oscillograph provides a permanent analog record of the input signal. A low-level calibration source is used to calibrate the system prior to each test.

\subsection{Digital Voltmeter System}

The digital voltmeter with the digital printer provides the capability for recording low-level millivolt data in digital form. The system, which will accept low-level millivolt signals directly, is equipped with an ohms-to-volts converter so that it can be used as a readout for resistive devices such as 


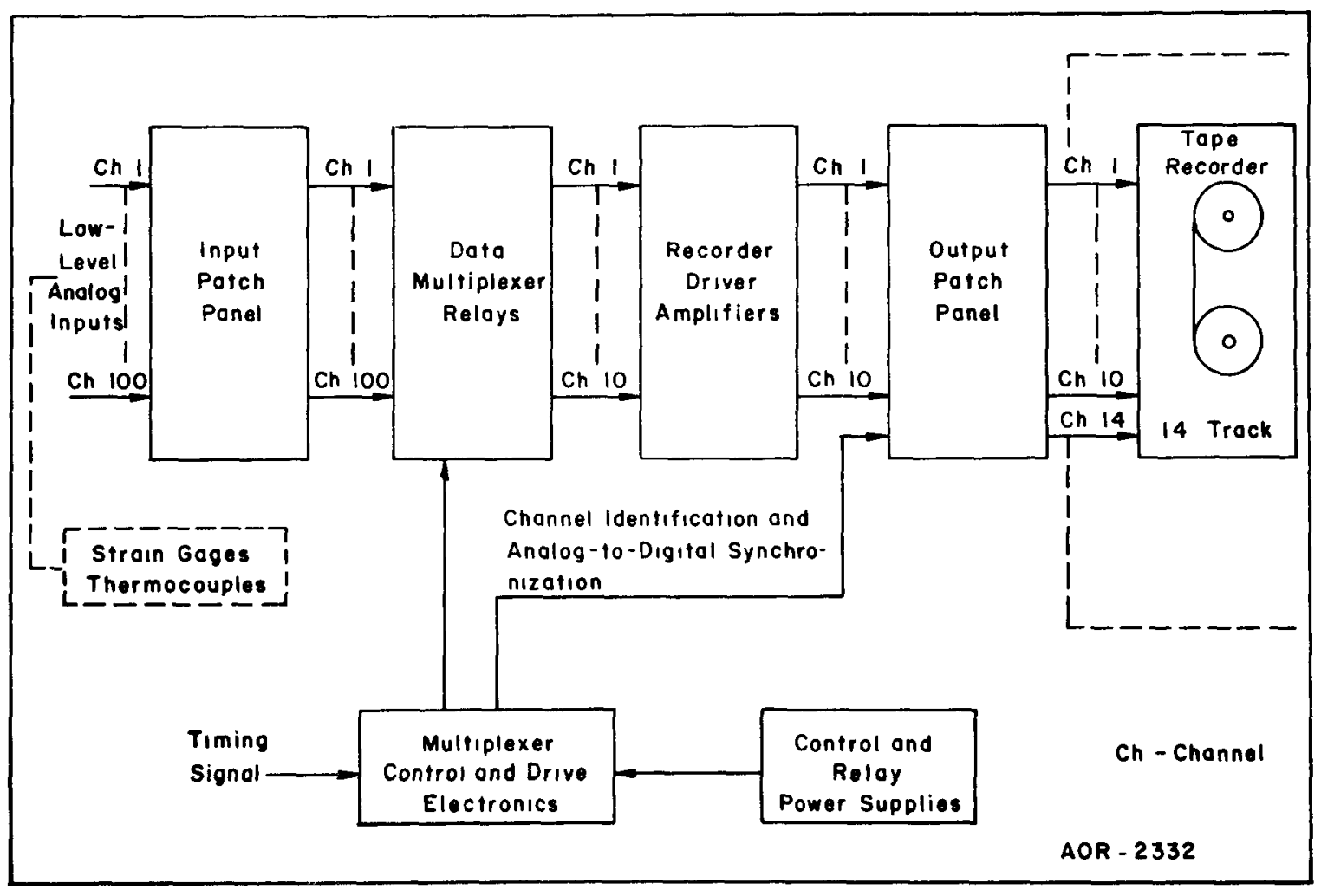

Fig. 15 Analog data multiplexing system.

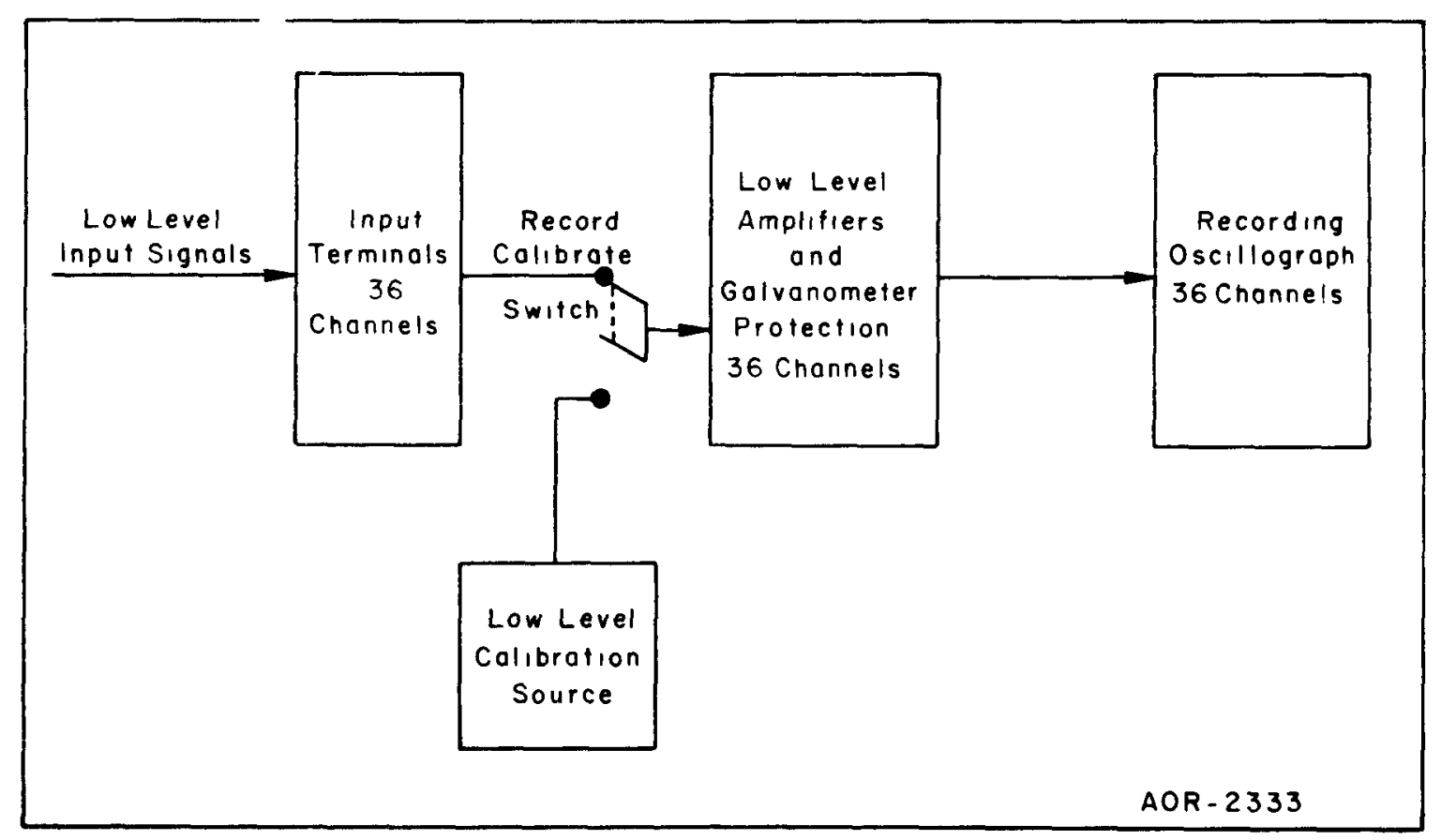

Fig. 16 Recording oscillograph system. 
the resistance thermometers. A manual-switch timer unit permits up to fifteen channels of resistance thermometers to be manually scanned and the data digitally recorded. Figure 17 is a block diagram of this system.

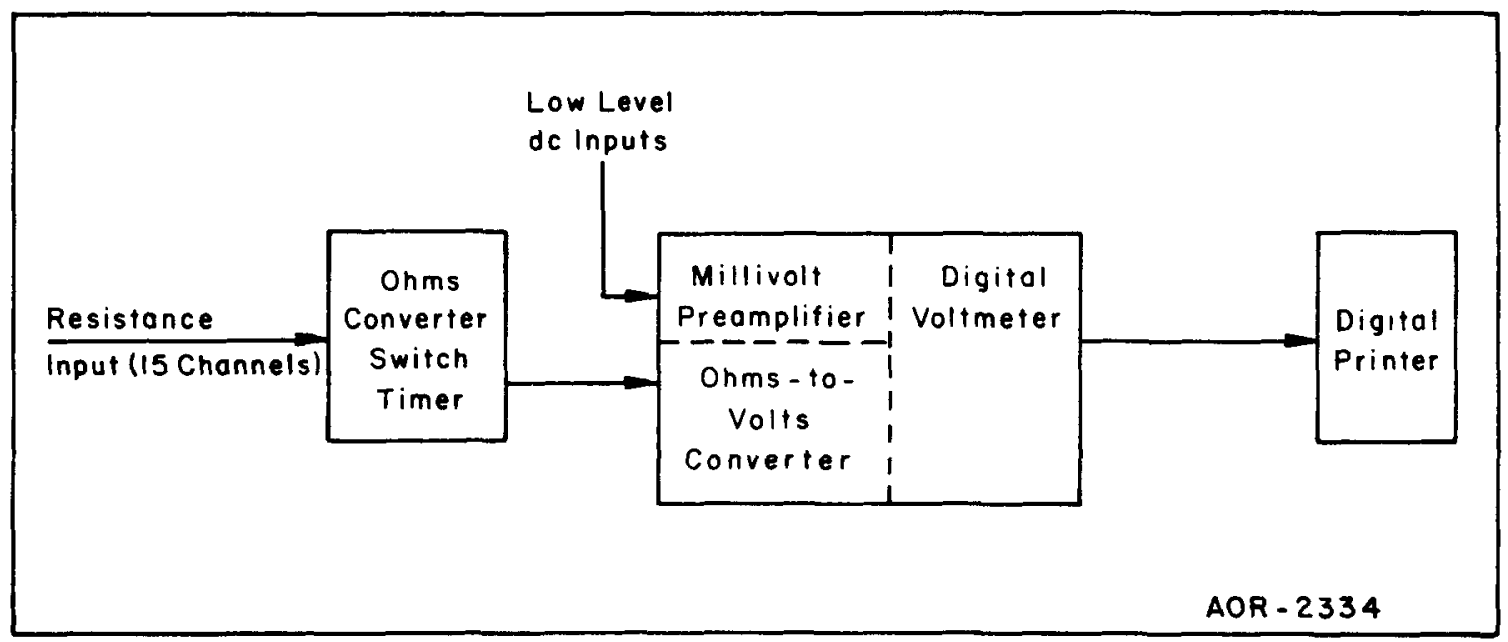

Fig. 17 Digital voltmeter and digital printer systems. 


\section{PROGRAM DESCRIPTION BEYOND FY-1969}

The CVTR In-Plant Testing Project will be completed in FY-1969. CVTR effort in FY-1970 will consist only of evaluation and reporting of test results. 


\section{REFERENCES}

1. L. C. Richardson, L。 J. Finnegan, R.J.Wagner, J.M.Waage, CONTEMPT -A Computer Program for Predicting the Containment Pressure-Temperature Response to a Loss-of-Coolant Accident, IDO-17220 (June 1967).

2. W. E. Barrow, CVTR Leakage Rate Instrumentation Evaluation, CVNA-295 (November 1967)。

3. G. E. Bingham, The Carolinas Virginia Tube Reactor Preliminary Leakage Rate Test Results, IDO-17273 (October 1968).

4. Ambient Vibration Survey and Mathematical Analysis of the CarolinasVirginia Tube Reactor, Earth Sciences, A Teledyne Company, IDO-ES-616 (ES-616-0968-2197) (September 1968).

5. Carolinas Virginia Nuclear Power Associates, Inc., Final Hazards Summary Report, CVNA-90 (January 1962). 